Baki, Y. (2018). 6., 7. ve 8. sınıf öğrencilerinin okuma tutumlarının Türkçe dersine ilişkin tutum üzerindeki etkisinde cinsiyetin rolü: Bir yapısal eşitlik modellemesi. Ana Dili Eğitimi Dergisi, 6(1), 238-259.

$\begin{gathered}\text { Ana Dili Eğitimi Dergisi } \\ \text { Journal of Mother Tongue Education } \\ \text { www.anadiliegitimi.com }\end{gathered}$
Geliş/Received: 14.11 .2017 Kabul/Accepted:27.01.2018

\title{
6., 7. ve 8. Sınıf Öğrencilerinin Okuma Tutumlarının Türkçe Dersine İlişkin Tutum Üzerindeki Etkisinde Cinsiyetin Rolü: Bir Yapısal Eşitlik Modellemesi
}

\author{
Yasemin $B A K i^{*}$
}

Öz

Bu araştırmada okuma tutumunun, Türkçe dersine ilişkin tutum üzerindeki etkisi ve bu etkide cinsiyetin rolünün yapısal eşitlik modellemesi yoluyla incelenmesi amaçlanmıştır. Araştırma ilişkisel tarama yoluyla gerçekleştirilmiştir. Çalışma grubu basit seçkisiz örnekleme yoluyla belirlenmiş olup 6,7 ve 8 . sınıfta öğrenim göre 317 öğrenciden oluşmaktadır. Verilerin toplanmasında Özbay ve Uyar (2009)'ın geliştirdiği “Okumaya Yönelik Tutum Ölçeği” ile Ünal ve Köse (2014)'nin geliştirdiği “Türkçe Dersine Yönelik Tutum Ölçeği” kullanılmıştır. Verilerin analizinde yapısal eşitlik modellemesi kullanılmıştır. Araştırmadaki modellere dair parametrelerin tahmininde maksimum olabilirlik (Maximum Likehood) yöntemi, uyum iyiliği değerlerinin incelenmesinde ise $\chi^{2} / \mathrm{df}, \mathrm{CFI}, \mathrm{GFI}, \mathrm{TLI}, \mathrm{NFI}, \mathrm{IFI}, \mathrm{RMSEA}$ ve SRMR uyum indeksleri kullanılmıştır. Araştırma sonucunda tüm hipotez modellerin geçerli olduğu; okuma tutumunun, Türkçe dersine ilişkin tutumun \%40'ını açıkladığı görülmüştür. Bunun yanı sıra erkek öğrencilere ilişkin oluşturulan modelde okuma tutumunun, Türkçe dersine iliş̧in tutumun \%30'unu, kız öğrencilere ilişkin oluşturulan modelde ise \% $40^{\prime} ı n ı$ açıkladığı belirlenmiştir.

Anahtar sözcükler: Okuma tutum, Türkçe dersi tutum, 6., 7. ve 8. sınıf öğrencileri, yapısal eşitlik modellemesi, cinsiyet

\section{The Role of Gender on its Effect on the Attitudes of $6^{\text {th }}, 7^{\text {th }}$ and $8^{\text {th }}$ Graders regarding their Attitudes towards the Turkish Course: A Structural Equation Modeling Study}

\begin{abstract}
In this study, the aim was to investigate the effect of the attitude towards reading on the attitude toward the Turkish course and the role of gender on this effect through structural equation modeling. The research was conducted, using relational survey model. The study group was formed through simple random sampling and consisted of 317 students who were $6^{\text {th }}, 7^{\text {th }}$ and $8^{\text {th }}$ graders. For data collection, the "Attitude Scale towards Reading" developed by Özbay and Uyar (2009) and the "Attitude Scale towards the Turkish Course" developed by Ünal and Köse (2014) were used. Structural equation modeling was used for data analysis. The Maximum Likelihood method was used for the prediction of the parameters for the models, and the $\chi^{2} / \mathrm{df}, \mathrm{CFI}, \mathrm{GFI}, \mathrm{TLI}$, $\mathrm{NFI}, \mathrm{IFI}, \mathrm{RMSEA}$ and SRMR fit indices were used for the analysis of the goodness of fit values. In the end, it was found that all hypothesis models were valid and that the reading attitude accounted for $40 \%$ of the attitude towards the Turkish course. In addition, it was determined that in the model for the male students the reading attitude accounted for $30 \%$ of the attitude toward the Turkish course and in the model for the female students, it accounted for $40 \%$.
\end{abstract}

Key Words: Reading attitude, attitude towards the Turkish course, $6^{\text {th }}, 7^{\text {th }}$ and $8^{\text {th }}$ graders, structural equation modeling, gender

\footnotetext{
* Yrd. Doç. Dr., Recep Tayyip Erdoğan Üniversitesi, Eğitim Fakültesi, Türkçe Eğitimi ve Sosyal Bilimler Eğitimi Bölümü, Rize. ysmnbaki@gmail.com.
} 


\section{Giriş}

Varoluşun temel gereksinimlerinden biri olan bilgiye erişimin en temel araçlarından biri olan okuma, sadece sembollerin anlamlandırılması ve seslendirilmesi değil okuyucu ile metin arasında kurulan ve kültürel değerlerin aktarımı ve korunmasını sağlayan yaşamsal bir süreçtir (Keleş, 2006). Okuma ayrıca bireyin düşünce evreninin yanı sıra duygu dünyasının gelişimini sağlayan besleyici bir güçtür (Katrancı, 2015). Bu beceri, akıl ve duygu birlikteliğinin sağlanması olan eğitim sürecinin temel ön şartlarından biri olmakla birlikte öğrenmenin temeli olarak da değerlendirilmektedir. Öğrenmeöğretme sürecinin de büyük oranda dil ve dile dayalı materyaller aracılığıyla okuma, anlama ve anlatma yoluyla gerçekleşmesi sebebiyle diğer becerilere oranla daha farklı bir öneme sahiptir (Belet, 2005; Demirel, 1992; Güneş, 2009; Köse ve Ünal, 2014). Türkçe Dersi Öğretim Programında kazandırılması hedeflenen temel becerilerden biri olan okuma, dil becerilerine oranla daha geniş yer tutmaktadır (Milli Eğitim Bakanlığı [MEB], 2015). Programda okuma becerisi kazanmış ve bu beceriyi yaşamın her alanında kullanabilecek üst düzey okurların yetiştirilmesi amaçlanmaktadır.

Okuma becerisinin kazandırılmasıyla amaçlanan nihai hedeflerden biri de bu becerinin bir alışkanlığa dönüşmesidir (Demirel, 2002; Güneş, 2007; Karatay, 2011). Okuma alışkanlığının kazanılmasında çeşitli değişkenler etkili olmakla birlikte dil öğretiminin temel bileşenlerinden biri olan de okuma tutum da bu süreçte etkin bir role sahiptir (Aydın, Kaya ve Bayraktar, 2015). Okumaya yönelik geliştirilen tutum, okumayı arttıran/azaltan duyusal ve duygusal bileşenlerden oluşan bir duygu olarak değerlendirilmektedir (Smith, 1990). Okuma sürecinin tüm bileşenlerini etkileyen okuma tutum (Conlon, Zimmer-Gembeck, Creed ve Tucker, 2006; Yamashita, 2007), öğrencilerin akademik gelişimleri hakkında da bilgi verici bir bileşendir (Kaniuka, 2010). Çünkü öğrencilerin okumaya yönelik tutumlarının arttırıması ile hedeflenen; öğrencilerin, okuma zevk ve alışkanlığı kazanmaları olmakla birlikte asıl gaye okuma alışkanlığını kazanmak değil öğrenmek için okuma eylemini bir araç olarak kullanacak idrak seviyesine gelebilmektir (Çınar, 2008). Bu bağlamda okuma tutum ve okuma alışkanlığı arasındaki ilişkini yanı sıra bu değişkenler akademik başarıyla da doğrudan ilişkilidir (Bağcl, 2010; Baş ve Şahin, 2012; Martinez vd., 2008; McKenna, Kear ve Ellsworth, 1995). Okuma tutumunun gelişimi beraberinde Türkçe dersine ilişkin tutumun gelişimine de olumlu yönde etki etmektedir (Demirel ve Epçaçan, 2012; Gelen, 2003; Mercan, 2017). Türkçe dersine yönelik geliştirilen olumlu tutum, bu derse ilişkin motivasyonu (Erdem ve Gözüküçük, 2013) ve akademik başarıyı pozitif yönde etkilemekte (Aktaş, 2013; Ateş, 2008) böylelikle öğrencilerin derse karşı ilgi göstermeleri ve dersi sevmelerini sağlamakta (Kaya, Arslantaş ve Şimşek, 2009), öğrenmenin ve beraberinde akademik başarının artmasını olumlu yönde etkilemektedir (Bölükbaş, 2010; Çalışkan, 2004). Nitekim alan yazındaki çeşitli araştırmalar da derse karşı geliştirilen tutumun, akademik başarıyı etkileyen önemli değişkenlerden biri olduğunu destekler niteliktedir (Altınok, 2004; Çakır 


\section{6., 7. ve 8. Sınıf Öğrencilerinin Okuma Tutumlarının Türkçe Dersine ilişkin Tutum Üzerindeki Etkisinde Cinsiyetin Rolü: Bir Yapısal Eşitlik Modellemesi}

(Kozcu), Şenler ve Taşkın (Göçmen), 2007). Bu sonuçlar duyuşsal değişkenlerin öğrenme sürecindeki etkisini göstermekle birlikte bu sürecin kilit yapısı olan dil becerilerinin kazanılmasına da doğrudan etki etmektedir.

Ana dili eğitimine ilişkin tutumun öğrenme sürecindeki işlevine karşın alan yazındaki araştırmalar, Türkçe dersinde hedeflenen kazanımlara yeterli düzeyde erişilemediğini (Demir ve Yapıcı, 2007; Kaya ve diğerleri, 2009), öğrencilerin Türkçe derslerinde kendilerini akademik olarak yeterli görmediklerini (Bıyıklı, 2014), dil becerilerini yeterince kazanamadıklarını ortaya koymaktadır (Deniz ve Tuna, 2006). Bununla birlikte birçok araştırma da Türkçe derslerinin bu konuda işlevsel olmadığını ve okuma becerisinin yeterince gelişmediğini göstermektedir (Akkılık, 2011; Baş, 2012; Campbell ve Kmiecik, 2004; Çeçen ve Deniz, 2015; İşeri, 2010; McKenna, Conradi, Lawrence, Jang ve Meyer, 2012; Schatz ve Krashen, 2006). Alan yazında okuma becerisiyle Türkçe dersine ilişkin tutum arasındaki ilişkiyi inceleyen çeşitli araştırmalar yer almaktadır (Mercan, 2017; Dağtaş, 2013; Ateş, 2008; Şahinli, 2008). Buna karşın okuma becerisinin kazanılması ve sürdürülmesinde etkili olan faktörlerden biri olan okuma tutumunun, Türkçe dersine ilişkin tutum üzerindeki etkisi ve açıklama oranın ortaya konulduğu her hangi bir araştırmaya erişilememiştir. Ayrıca okuma tutum (Balcı, Uyar ve Büyükikiz, 2012; Baş, 2012; Bozpolat, 2010; Byro, 2000; Çeçen ve Deniz, 2015; Epçaçan, 2012; Logan ve Johnston, 2009; Öztürk ve diğerleri, 2016; Schatz ve Krashen, 2006; Schooten ve Glopper, 2002; Stokmans, 1999; Suna, 2006; Yalınkılıç, 2007) ve Türkçe dersine ilişkin tutuma (Bıyıklı, 2014; Deniz ve Tuna, 2006; Kaya ve diğerleri, 2009; Bölükbaş, 2010; Gür, Dilci, Şener ve Yıldırım, 2013; Okur ve Özsoy, 2013; Zorbaz ve Habeş, 2015) dair yapılan araştırmalarda kız öğrencilerin tutumlarının, erkeklere göre manidar düzeyde farklılık gösterdiği tespit edilmiştir. Yapılan alan yazın taramasında Türkçe dersine ilişkin tutum ölçeklerinin sınırlı sayıda olduğu ve bu ölçeklerin 1-5 ile 6-8 eğitim düzeyine uygun olarak hazırlandığı görülmüştür. Türkçe dersine ilişkin tutum ölçeklerinin sınırlılı̆ı sebebiyle 6, 7 ve 8. sınıf örnekleminde gerçekleştirilen bu araştırmada okuma tutumunun, Türkçe dersine ilişkin tutum üzerindeki etkisinin ve açıklama oranın yanı sıra bu etkide cinsiyetin rolünün incelenmesi amaçlanmıştır. Bu etkinin incelenmesi için alan yazın taramasına dayalı oluşturulan model, Şekil 1'de sunulmuştur.

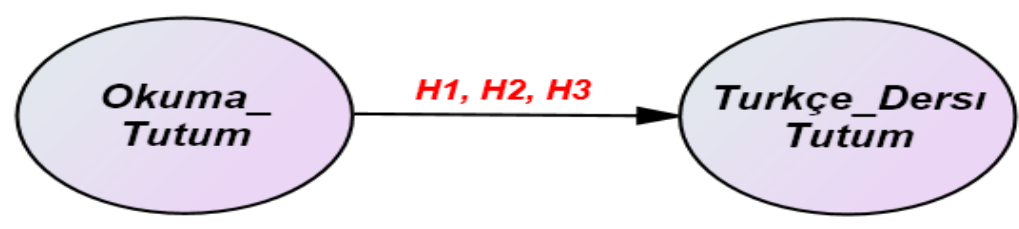

Şekil 1. Araştırma modeli 
Yukarıdaki modele göre bu araştırmada 6., 7. ve 8. sınıf öğrencilerinin okuma tutumlarının, Türkçe dersine ilişkin tutuma etkisi ve bu etkide cinsiyetin rolünün tespit edilmesi amaçlanmıştır. Modelden hareketle bu araştırmada test edilmek üzere önerilen hipotezler aşağıda sunulmuştur.

$\mathbf{H}_{1}:$ 6, 7 ve 8. sınıf öğrencilerinin okuma tutumları, Türkçe dersine ilişkin tutumlarını manidar düzeyde yordamaktadır.

$\mathbf{H}_{\mathbf{2}}$ : Erkek öğrencilerin okuma tutumları, Türkçe dersine ilişkin tutumlarını manidar düzeyde yordamaktadır.

$\mathbf{H}_{3}$ : Kız öğrencilerin okuma tutumları, Türkçe dersine ilişkin tutumlarını manidar düzeyde yordamaktadır.

\section{Yöntem}

\section{Araştırmanın Modeli}

6., 7. ve 8. sınıf öğrencilerinin okuma tutumlarının, Türkçe dersine ilişkin tutum üzerindeki etkisi ve açıklama oranın yanı sıra bu etkide cinsiyetin rolünün belirlenmesinin amaçlandığı bu araştırma, tarama modellerinden ilişkisel tarama modelinde tasarlanmıştır. İlgili modelde, iki veya daha fazla değişkenin birlikte değişimi veya bu değişimin derecelendirilmesi amaçlanmaktadır (Karasar, 2011).

\section{Araştırmanın Örneklemi}

Araştırmadaki katılımcılar; seçkisiz örnekleme yöntemlerinden, basit seçkisiz örnekleme yoluyla sosyoekonomik düzey açısından alt-orta ve üst düzeydeki üç ortaokuldan seçilmiş olup 6, 7 ve 8. sınıfta öğrenim gören 317 öğrenciden oluşmaktadır. Demografik özellikleri incelendiğinde; öğrencilerin 170'i (\%55.5) kız, 147'si (\%46.4) erkek olmakla birlikte 148'i (\%46.7) 6. sınıf, 103'ü (\%32.5) 7. sınıf, 66’sı (\%20.8) 8. sınıfta öğrenim görmektedir.

\section{Verilerin Toplanması}

Araştırmanın verileri, 19. 04. 2016 tarihinde toplanmıştır. Araştırma öncesinde ölçeklerin uygulanacağı okullar için gerekli izinler alınmıştır. Araştırmanın gerçekleştirileceği üç ortaokulun ders programları incelenmiş; öğretmenlere ve öğrencilere araştırmanın amacı, kullanılacak ölçekler ve uygulama süreci hakkında gerekli bilgiler verilmiştir. Ölçekler, her üç okulda da aynı gün ve ders saatinde yapılmış olup her sınıf düzeyinde de aynı ders saatinde uygulanmıştır. Ölçeklerin uygulaması 40 dakikalık sürede gerçekleştirilmiş olup katılımcılara ücret ödenmemiştir.

\section{Veri Toplama Aracı}




\section{6., 7. ve 8. Sınıf Öğrencilerinin Okuma Tutumlarının Türkçe Dersine ilişkin Tutum Üzerindeki Etkisinde Cinsiyetin Rolü: Bir Yapısal Eşitlik Modellemesi}

Araştırma veriler, Okumaya Yönelik Tutum Ölçeği ve Türkçe Dersine Illişkin Tutum Ölçeği aracılığıyla toplanmış olup bu ölçme araçlarına dair geçerlik ve güvenirlik çalışmaları aşağıda sunulmuştur.

\section{Okumaya Yönelik Tutum Ölçeği}

Özbay ve Uyar (2009) tarafından ilköğretim ikinci kademe öğrencilerinin $(6,7,8)$ okuma tutumlarını ölçmek için geliştirilen bu ölçme aracı “Okumaya Yönelik Tutum Ölçeği (OYTÖ)" olarak adlandırılmıştır. Bu ölçme aracında olumlu ifadelere verilen cevaplar için "hiç katılmıyorum (1)", "katılmıyorum (2)", "kısmen katılıyorum (3)", "katılıyorum (4)", "tamamen katılıyorum (5)" olmak üzere $5^{\prime}$ li Likert tipinde hazırlanmıştır. Olumsuz ifadelere verilen cevaplar için ise bunun tersi kodlama yapılmıştır. Ölçeğin yapı geçerliğini incelemek için açımlayıcı ve doğrulayıcı faktör analizi kullanılmıştır. Açımlayııı faktör analizi sonucunda ölçeğin 25 maddeden ve dört faktörlü bir yapıdan oluştuğu tespit edilmiştir. Bu faktörler; "serbest okumaya yönelik tutumlar", "kitap okumaya yönelik tutumlar", "genel okumaya yönelik tutumlar" ve "akademik okumaya yönelik tutumlar" olarak adlandırılmıştır. Bu faktörlerden birincisi okul dışı serbest okumaya, ikincisi kitaplara, üçüncüsü genel okumaya, dördüncüsü ise akademik okumaya ilişkin tutumları içeren bir yapıdadır. Bu ölçme aracının güvenirliğinin belirlenmesi amacıyla Cronbach Alpha iç tutarlık katsayısı kullanılmıştır. Bu kat sayı ölçeğin tümü için .91; birinci faktör için .85, ikinci faktör için .83, üçüncü faktör için .85, dördüncü faktör için .71 olarak hesaplanmıştır. Bu araştırmada ölçeğe ilişkin yapılan doğrulayıcı faktör analizi sonucunda, yapısal modelin uyum indekslerinin kabul edilebilir düzeyde olduğu ifade edilebilir $\left(\chi^{2}=428.03, s d=2.65(p<.01), R M S E A=.04, S R M R=.04, G F I=.91, C F I=.99, N F I=.97, A G F I=.90\right)$.

Ölçeğe ilişkin geçerlik ve güvenirlik çalışması bu araştırma için yapılmış olup analizler aşağıda sunulmuştur.

Doğrulayıcı Faktör Analizi: Ölçme aracının faktör yapılarının, bu araştırma için doğrulanıp doğrulanmadığını tespit etmek amacıyla gerçekleştirilen doğrulayıcı faktör analizi (DFA) sonuçları Şekil 2'de sunulmuştur. 


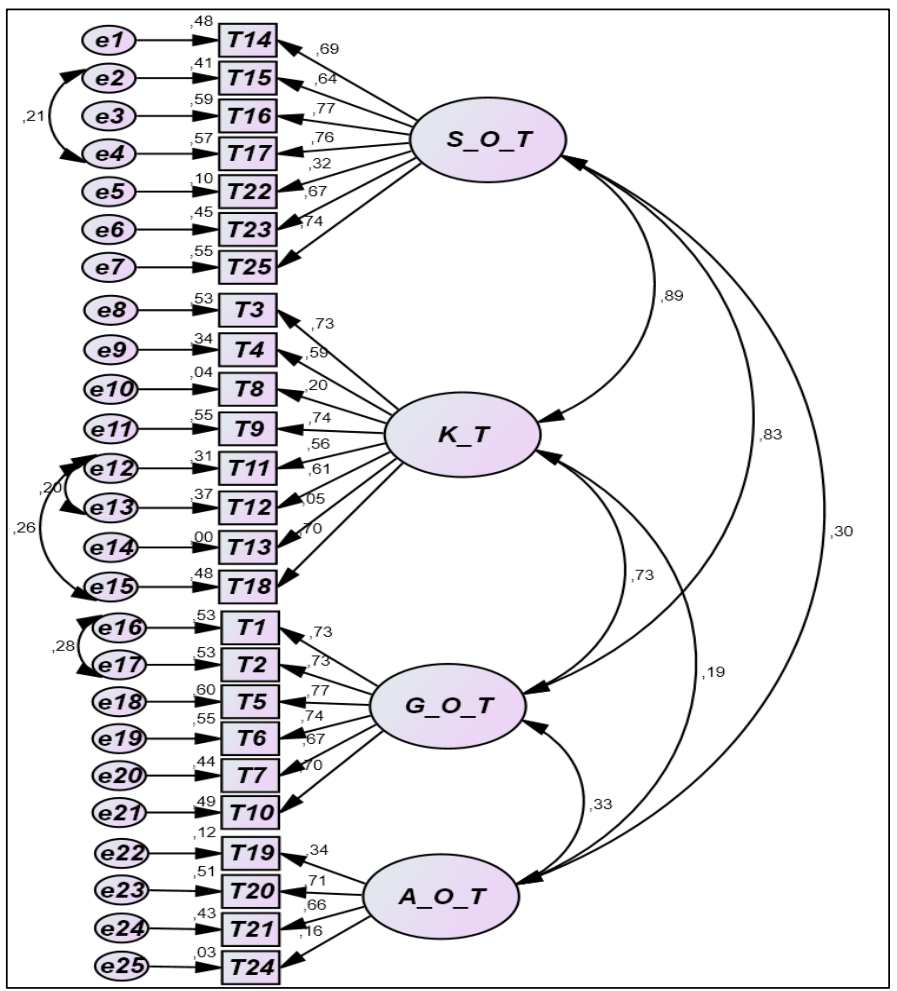

Şekil 2. Okuma Tutum Ölçeğine Iliş̧kin Doğrulayıcı Faktör Analizi

Doğrulayıcı faktör analizi (DFA) 25 madde ve dört faktörden oluştuğu doğrulanan ölçeğin uyum iyiliği indekslerinin $\left(\chi^{2} / s d=2.93(p<.01), G F I=.84, C F I=.85, R M S E A=.07\right.$ ve $\left.S R M R=.10\right)$ kabul edilebilir düzeyde olduğu görülmektedir (Hu ve Bentler, 1999; Jöreskog ve Sörbom, 1993; Kline, 2011; Sümer, 2000). Bu sonuçlara göre ölçeğin orijinal formundaki faktör yapılarının bu araştırma için doğrulandığı görülmektedir.

Güvenirlik Analizi: Güvenirlik analizi sonucunda Cronbach Alpha iç tutarlık katsayısı; ölçeğin tümünde .80 , "serbest okumaya yönelik tutumlar" boyutunda .73, "kitap okumaya yönelik tutumlar" boyutunda .75, "genel okumaya yönelik tutumlar" boyutunda .76, "akademik okumaya yönelik tutumlar" boyutunda ise .84 olarak bulunmuştur. Bu sonuçlara göre ölçeğin yüksek düzeyde güvenirliğe sahip olduğu söylenebilir.

\section{Türkçe Dersine Yönelik Tutum Ölçeği}

Bu ölçme aracı, Ünal ve Köse (2014) tarafından ortaokul 6., 7. ve 8. sınıftaki öğrencilerin Türkçe dersine ilişkin tutumlarını belirlemek için geliştirilmiştir. "Türkçe Dersine Yönelik Tutum Ölçeği” olarak adlandırılan bu ölçekte olumlu ifadelere verilen cevaplar için "hiç katılmıyorum (1)", "katılmıyorum (2)", "kararsızım (3)", "katılıyorum (4)”, "tamamen katılıyorum (5)” olmak üzere 5'li Likert tipinde hazırlanmıştır. Olumsuz ifadelere verilen cevaplar için ise bunun tersi kodlama yapılmıştır. Açımlayııı faktör analizi sonucunda ölçeğin 27 madde ve "derse yönelik ilgi ve sevgi", "derse ilişkin olumsuz tutum" ve "derse yönelik etkinlikler" olmak üzere üç faktörlü bir yapıdan 


\section{6., 7. ve 8. Sınıf Öğrencilerinin Okuma Tutumlarının Türkçe Dersine ilişkin Tutum Üzerindeki Etkisinde Cinsiyetin Rolü: Bir Yapısal Eşitlik Modellemesi}

oluştuğu görülmüştür. Cronbach Alpha iç tutarlık katsayısı, ölçeğin tümünde .91 , birinci faktörde .92 , ikinci faktörde .84 ve üçüncü faktörde .73 olarak belirlenmiştir. Yapılan DFA sonucunda yapısal modelin uyum indekslerinin $\left(\chi^{2} / s d=1.90(p<.01), \operatorname{RMSEA}=.066, \mathrm{SRMR}=.072, \mathrm{GFI}=.85, \mathrm{CFI}=.86, \mathrm{NFI}=.85\right)$ kabul edilebilir düzeyde olduğu görülmüştür.

Bu araştırma için ölçeğe dair yapılan güvenirlik ve geçerlik çalışmasına dair analizler aşağıda sunulmuştur.

Doğrulayıcı Faktör Analizi: Ölçeğin asıl formundaki faktörlerin bu araştırma için doğrulanıp doğrulanmadığını incelemek amacıyla yapılan DFA sonuçları Şekil 3’te sunulmuştur.

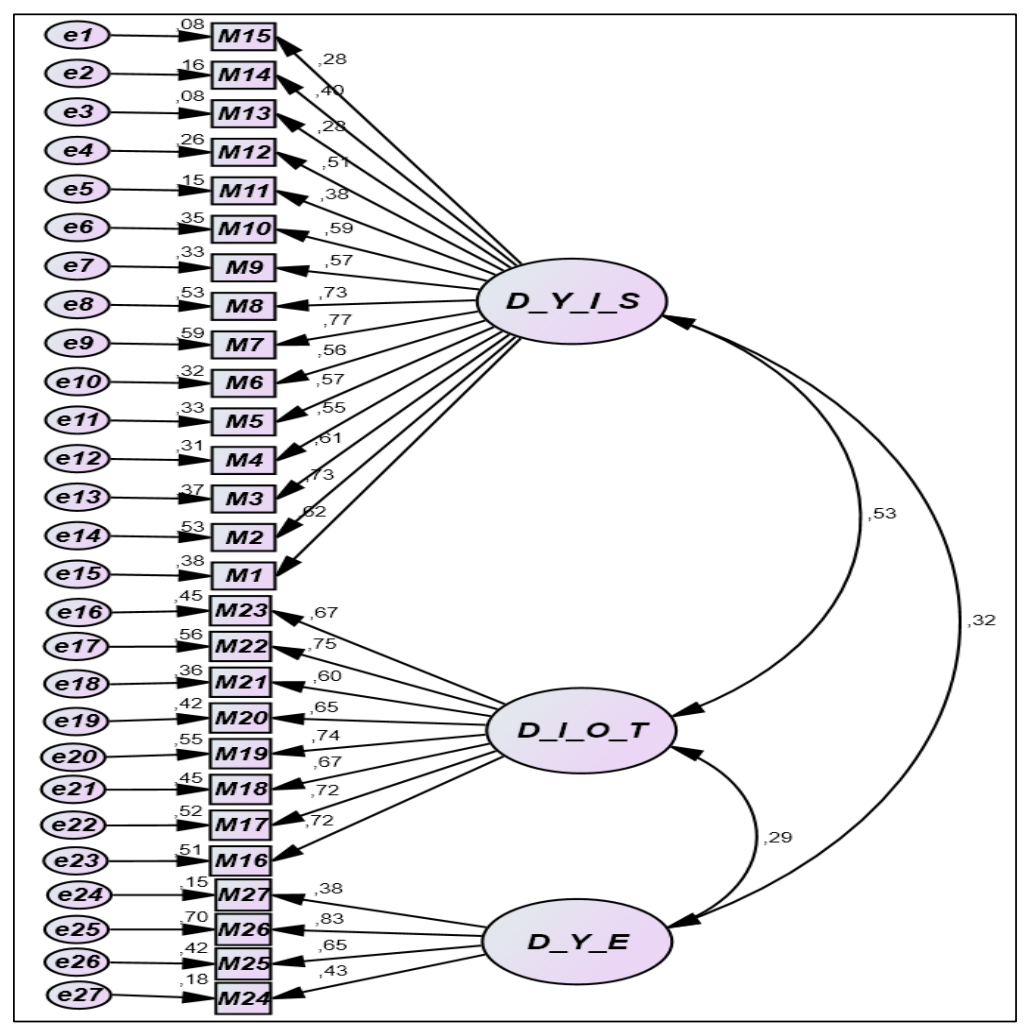

Şekil 3. Türkşe Dersine Yönelik Tutum Ölçeğine Iliş̧kin Doğrulayıcı Faktör Analizi

DFA sonucunda ölçeğin üç faktörden ve 27 maddeden oluştuğu gözlenmiştir. Yapılan analizler sonucunda ölçeğin uyum iyiliği indekslerinin $\left(\chi^{2} / s d=2.34 \quad(p<.01), G F I=.85, C F I=.85\right.$, $R M S E A=.06$ ve $S R M R=.07$ ) kabul edilebilir düzeyde olduğu ve ölçeğin asıl formundaki faktör yapılarının doğrulandığı gözlenmiştir.

Güvenirlik Analizi: Ölçeğe dair yapılan güvenirlik analizi sonucunda, Cronbach Alpha iç tutarlık katsayısı ölçeğin tümünde .78, "derse yönelik ilgi ve sevgi" boyutunda .63, "derse ilişkin olumsuz tutum" boyutunda .73 ve "derse yönelik etkinlikler" boyutunda .83 olarak bulunmuştur. Bu sonuçlara göre bu ölçeğin güvenilir bir ölçme aracı olduğu doğrulanmıştır. 


\section{Verilerin Analizi}

Araştırmada elde edilen verilerin analizinde öncelikle frekans, yüzde, ortalama, basıklık ve çarpıklık değerleri hesaplanmıştır. Değişkenler arasındaki ilişkilerin analizinde ise Yapısal Eşitlik Modellemesi (YEM) kullanılmıştır. Verilerin modele uyumunu incelemek için alan yazında yaygın olarak tercih edilen iki aşamalı yöntem kullanılmıştır (Jöreskog ve Sörbom, 1993; Meydan ve Şeşen, 2011). Illk olarak ölçekler incelenmiş, eksik güvenilir olmadığı düşünülen ölçekler araştırmadan çıkarıımış, araştırmaya dâhil edilen ölçekler kodlanarak sınıflandırılmıştır. Ardından ölçekler geçerlilik ve güvenirlik açısından incelenmiş, her ölçeğe ilişkin DFA ve güvenirlik analizine dair sonuçlar, ölçeklere dair açıklamaların yapıldığı bölümde verilmiştir.

Araştırmanın ikinci aşamasında YEM analizine ilişkin varsayımlar incelenmiştir. Bu aşamada ilk olarak örneklem büyüklüğü ve çok değişkenli normallik varsayımları kontrol edilmiştir. Bu analizde önerilen örneklem büyüklüğünün 100-150 olması yeterli görülmektedir (Kline, 2011). Verilere ilişkin çok değişkenli normallik varsayımının kontrol edilmesi için gerekli ön koşul olan tek değişkenli normallik dağıımı için her değişkene dair çarpıklık (skewness) ve basıklık (kurtosis) kat sayıları hesaplanmıştır (Kline, 2011). Çoklu değişkenli normallik varsayımının kontrol edilmesinde ise Mardia'nın normalleştirilmiş çok değişkenli basıklık katsayısı kullanılmıştır (Raykov ve Marcoulides, 2008). Varsayımların incelenmesinin ardından modelin veri setiyle uyumu kontrol edilmiştir. YEM analizinde parametrelerin tahmininde maksimum olabilirlik (Maximum Likehood) tekniği, veri setinin modele uyumunun değerlendirilmesinde ise $\chi^{2} / d f, C F I, G F I, T L I, N F I, I F I, R M S E A$ ve SRMR uyum indeksleri kullanılmıştır. Bu indekslerin modele uyum düzeyleri ve yorumları Tablo 1'de yer sunulmuştur (Hu ve Bentler, 1999; Klem, 2000; Kline, 2011).

Tablo 1. Yapısal eşitlik modelleri uyum indeksleri

\begin{tabular}{ccc}
\hline Uyum indeksleri & Iyi uyum & Kabul edilebilir Uyum \\
\hline$\chi^{2} / s d$ & $0 \leq \chi^{2} / \mathrm{sd} 0 \leq 2$ & $2<\chi^{2} / \mathrm{sd} \leq 5$ \\
$R M S E A$ & $0 \leq \mathrm{RMSEA} \leq .05$ & $.05<\mathrm{RMSEA} \leq .08$ \\
$S R M R$ & $0 \leq \mathrm{SRMR} \leq .05$ & $.05 \leq \mathrm{SRMR} \leq .10$ \\
$I F I$ & $0.95 \leq \mathrm{IFI}<1.00$ & $0.90 \leq<\mathrm{IFI}<0.95$ \\
$T L I$ & $0.95 \leq \mathrm{TLI}<1.00$ & $0.90 \leq \mathrm{TLI}<0.95$ \\
CFI & $0.95 \leq \mathrm{CFI}<1.00$ & $0.90 \leq \mathrm{CFI}<0.95$ \\
GFI & $0.95 \leq \mathrm{GFI}<1.00$ & $0.90 \leq \mathrm{GFI}<0.95$ \\
$\mathrm{NFI}$ & $0.95 \leq \mathrm{NFI}<1.00$ & $0.90 \leq \mathrm{NFI}<0.95$
\end{tabular}

Bulgular

Bu araştırmadan elde edilen bulgular iki bölümde sunulmuştur. Birinci bölümde betimleyici istatistiklere, ikinci bölümde ise yapısal eşitlik modellemesinde yer alan değişkenler arasındaki ilişkilere ait tahminlere, değişkenlerin açıklanma oranlarına ve model uyumlarına dair bulgulara yer verilmiştir. 


\section{6., 7. ve 8. Sınıf Öğrencilerinin Okuma Tutumlarının Türkçe Dersine ilişkin Tutum Üzerindeki Etkisinde Cinsiyetin Rolü: Bir Yapısal Eşitlik Modellemesi}

\section{Model Değişkenlerine iliş̧kin Betimleyici istatistikler}

Modellerde yer alan değişkenlere (SOT, KT, GOT, AOT, DYIS, DIOT, DYE) ait betimsel istatistikler Tablo 2' de sunulmuştur.

Tablo 2. Ölçüm maddelerine ilişkin betimleyici istatistikler

\begin{tabular}{|c|c|c|c|c|c|c|c|c|}
\hline \multicolumn{9}{|c|}{ Faktörler } \\
\hline & & SOT & KT & GOT & AOT & DYIS & DIOT & DYE \\
\hline \multirow{4}{*}{$\underbrace{\frac{\xi}{\partial}} \frac{\frac{1}{2}}{\frac{2}{2}}$} & $M$ & 25.37 & 25.22 & 23.56 & 13.75 & 45.97 & 31.07 & 14.80 \\
\hline & SS & 5.97 & 6.00 & 5.15 & 3.18 & 9.74 & 6.87 & 3.23 \\
\hline & SK & -.40 & -.03 & -.87 & .02 & -.11 & -.61 & -.15 \\
\hline & K & -.19 & -.10 & .53 & -.41 & -.12 & -.21 & -.59 \\
\hline \multirow{4}{*}{$\frac{\text { 弟 }}{\frac{\text { 立 }}{2}}$} & $M$ & 23.82 & 24.34 & 22.74 & 13.35 & 44.98 & 29.52 & 14.40 \\
\hline & SS & 6.04 & 5.91 & 5.39 & 3.23 & 9.98 & 7.00 & 3.25 \\
\hline & SK & -.22 & -.17 & -.77 & .06 & -.07 & -.40 & .05 \\
\hline & K & -.27 & -.11 & .15 & -.38 & -.14 & -.35 & -.82 \\
\hline \multirow{4}{*}{$\underline{\underline{N}}$} & $M$ & 26.71 & 25.98 & 24.27 & 14.10 & 46.82 & 32.40 & 15.14 \\
\hline & SS & 5.60 & 5.99 & 4.84 & 3.09 & 9.48 & 6.48 & 3.19 \\
\hline & SK & -.54 & -.08 & -.93 & .01 & -.13 & -.83 & -.34 \\
\hline & K & -.07 & -.23 & .92 & -.44 & -.09 & .14 & -.24 \\
\hline
\end{tabular}

Tablo 2'ye göre modeldeki tüm değişkenlere (SOT, KT, GOT, AOT, DYIS, DIOT, DYE) dair aritmetik ortalamaların, ilgili puan aralığının orta noktasının üzerinde olduğu ve bu değerlerin 13.35 ile 46.82 arasında değiştiği gözlenmiştir. Standart sapma değerleri ise ortalamalara yakın sayılabilecek değerlerdedir. Tek değişkenli normallik varsayımının sağlanabilmesi için değişkenlere dair çarpıklık (skewness) ve basıklık (kurtosis) kat sayıları sırasıyla |3.0|'ten ve |10.0|'dan büyük olmamalıdır (Kline, 2011). Araştırmadaki değişkenlere ilişkin çarpıklık değerleri .02 ile -.54; basıklık değerleri ise .07 ile .92 aralığında değişmekte olup verilere dair tek değişkenli normalliğin sağlandığı görülmüştür. Çok değişkenli normallik varsayımının kontrolünde ise Mardia'nın normalleştirilmiş çok değişkenli basıklık katsayısı hesaplanmış, bu katsayı, tüm gruplar için (tüm örneklem, kız, erkek) sırasıyla 10.18, 9.69, 11.44 olarak bulunmuştur. Bu dağılıma ilişkin varsayımın sağlanması için kritik değer; Raykov ve Marcoulides (2008)'in önerdiği $p(p+2)$ ( $p$ : gözlenen değişken sayısı) denkleme göre hesaplanmış olup yapılan analizler sonucunda bu değer 63 olarak bulunmuştur. Bu varsayımın sağlanması için denklemden elde edilen bu değer, basıklık katsayısından büyük olmalıdır (Raykov ve Marcoulides, 2008). Denklemden elde edilen değer (63), çok değişkenli basıklık katsayılarından $(10.18,9.69,11.44)$ büyük için çok değişkenli normallik varsayımının da sağlandığı gözlenmiştir.

\section{Ölçme Modeline Illişkin Bulgular}

6, 7 ve 8. sınıf öğrencilerinin okuma tutumlarının, Türkçe dersine yönelik tutumlarını yordama düzeyine dair oluşturulan modellere (tüm örneklem, erkek öğrenciler, kız öğrenciler) ilişkin sonuçlar Şekil $4_{(a, b, c)}$ te gösterilmiştir. 


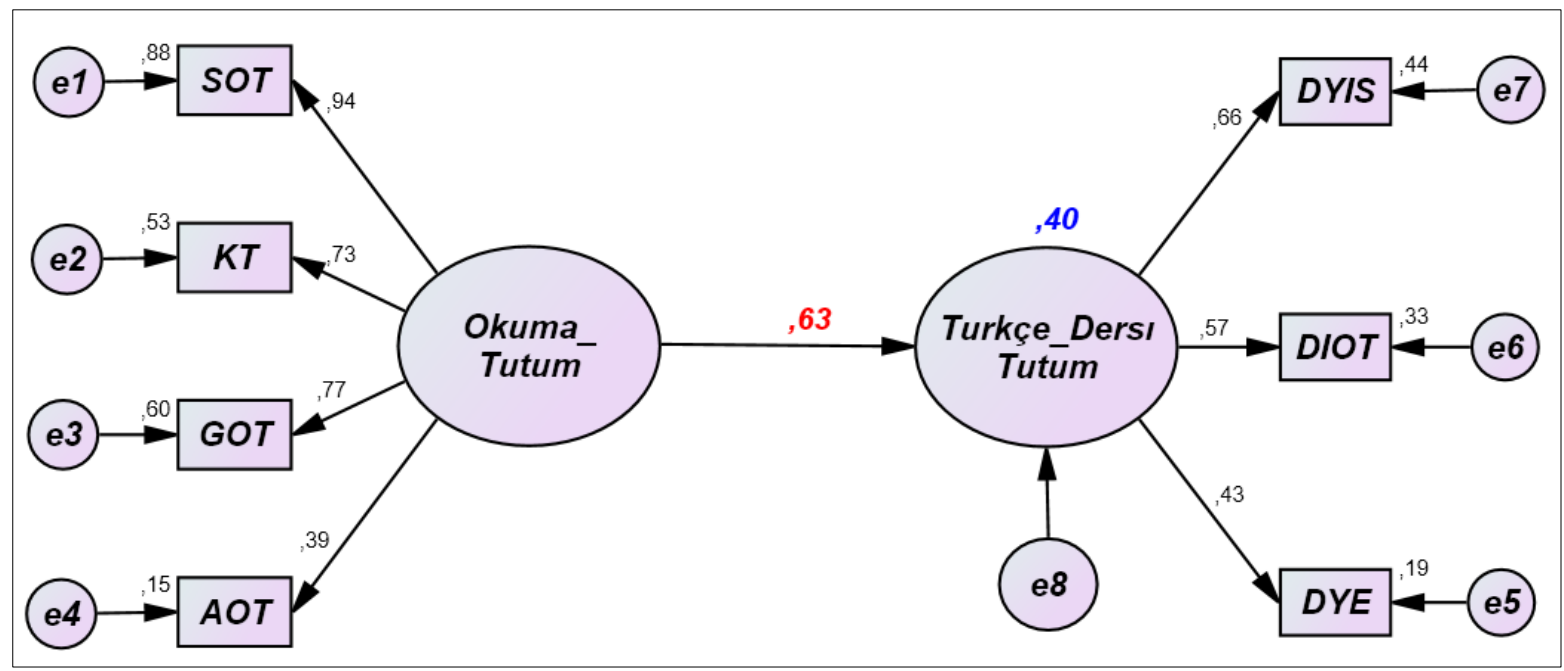

Şekil 4a. Tüm örneklem

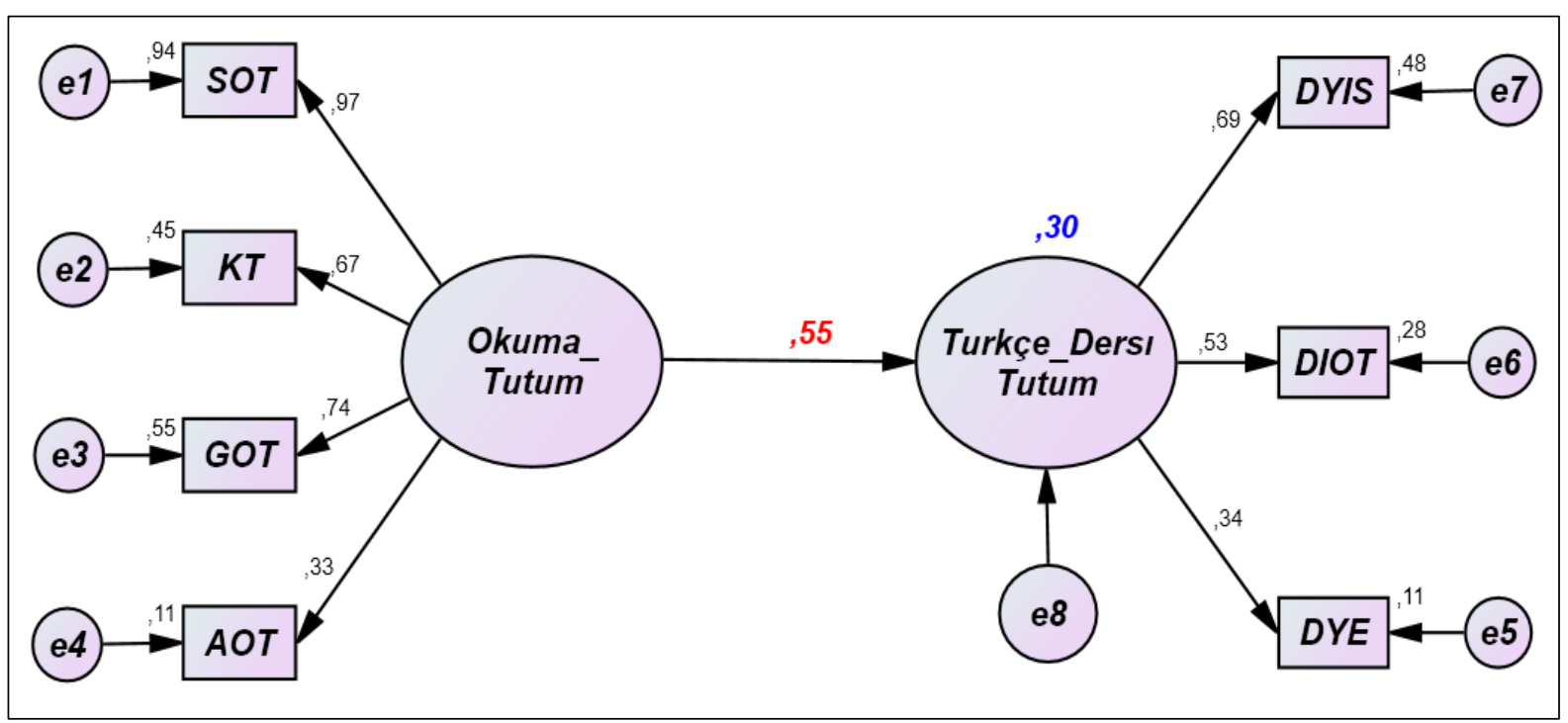

Şekil 4b. Erkek öğrenciler

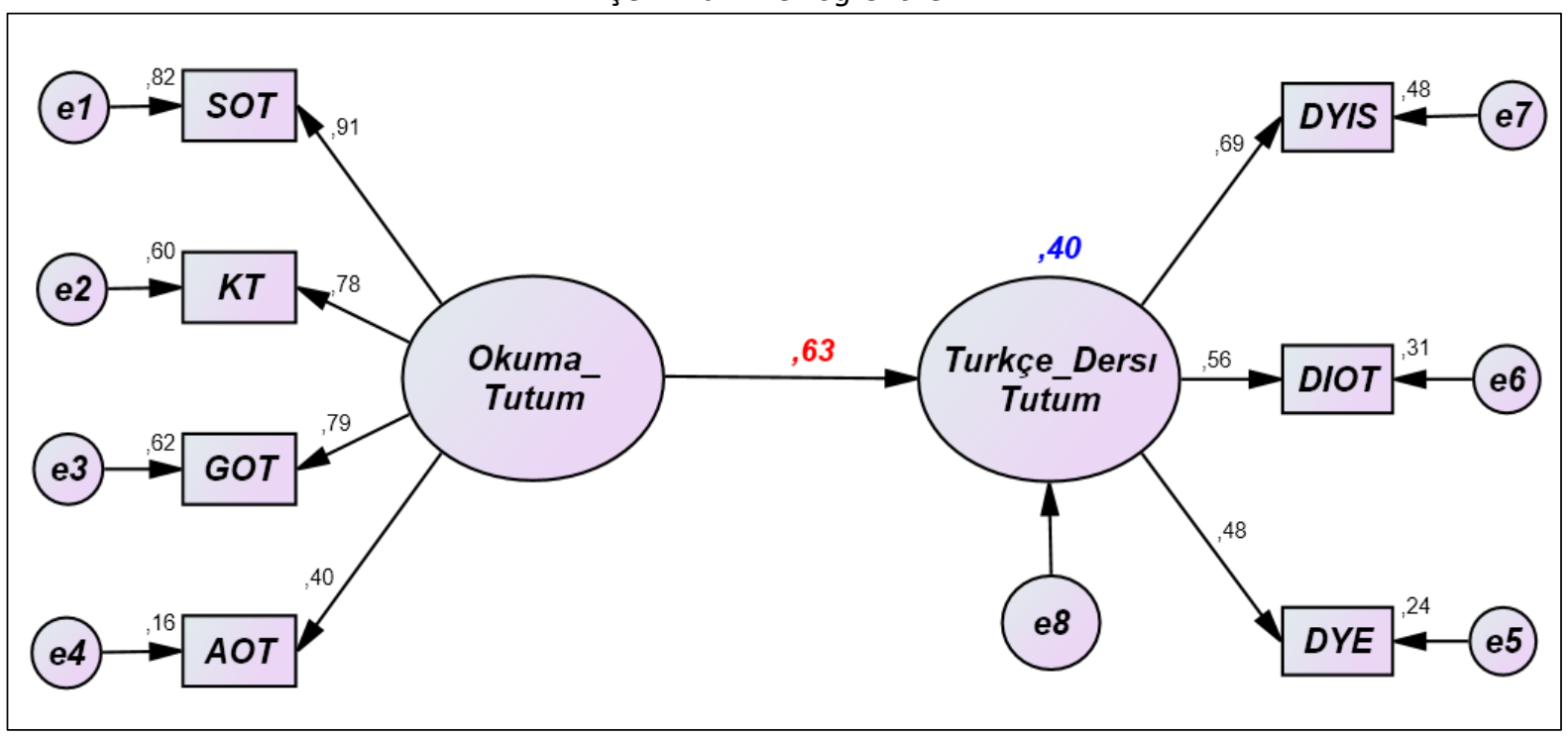

Şekil 4c. Kız öğrenciler 


\section{6., 7. ve 8. Sınıf Öğrencilerinin Okuma Tutumlarının Türkçe Dersine ilişkin Tutum Üzerindeki Etkisinde Cinsiyetin Rolü: Bir Yapısal Eşitlik Modellemesi}

Okuma tutumunun, Türkçe dersine ilişkin tutum üzerindeki etkisini belirlemek amacıyla oluşturulan yapısal eşitlik modellemesi sonucunda; uyum iyiliği indekslerinin, tüm örnekleme ilişkin modelde $\left(\chi^{2} / d f=6.73 ; G F I=.93 ; C F I=.90 ; R M S E A=.13 ; S R M R=.08\right)$, erkek öğrencilere ilişkin modelde $\left(\chi^{2} / d f=4.29 ; G F I=.90 ; C F I=.86 ; R M S E A=.15 ; S R M R=.09\right)$ ve kı öğrencilere ilişkin modelde $\left(\chi^{2} / d f=3.68\right.$; $G F I=.93 ; C F I=.91 ; R M S E A=.08 ; S R M R=.12$ ) kabul edilebilir düzeyde olduğu belirlenmiştir. Yapısal modellere ilişkin analizler sonucunda, okuma tutum gizil değişkeninin faktör yüklerinin tüm örnekleme ilişkin model için .39 ile .94; erkek öğrencilere ilişkin modelde .33 ile .97; kız öğrencilere ilişkin modelde ise .40 ile .91 arasında değiştiği belirlenmiştir. Türkçe dersi tutum gizil değişkenine ait faktör yükleri ise tüm örnekleme ilişkin modelde .43 ile .66; erkek öğrencilere ilişkin modelde .34 ile .69 ve kız öğrenciler için kurulan modelde .48 ile .69 arasında değiştiği gözlenmiştir. Yapısal eşitlik modellerine dair bulgular Tablo 3'te gösterilmektedir.

Tablo 3. Okumaya tutumunun Türkşe dersi tutum üzerindeki etkisine iliş̧in standardize edilmiş regresyon ağırlığı sonuçları

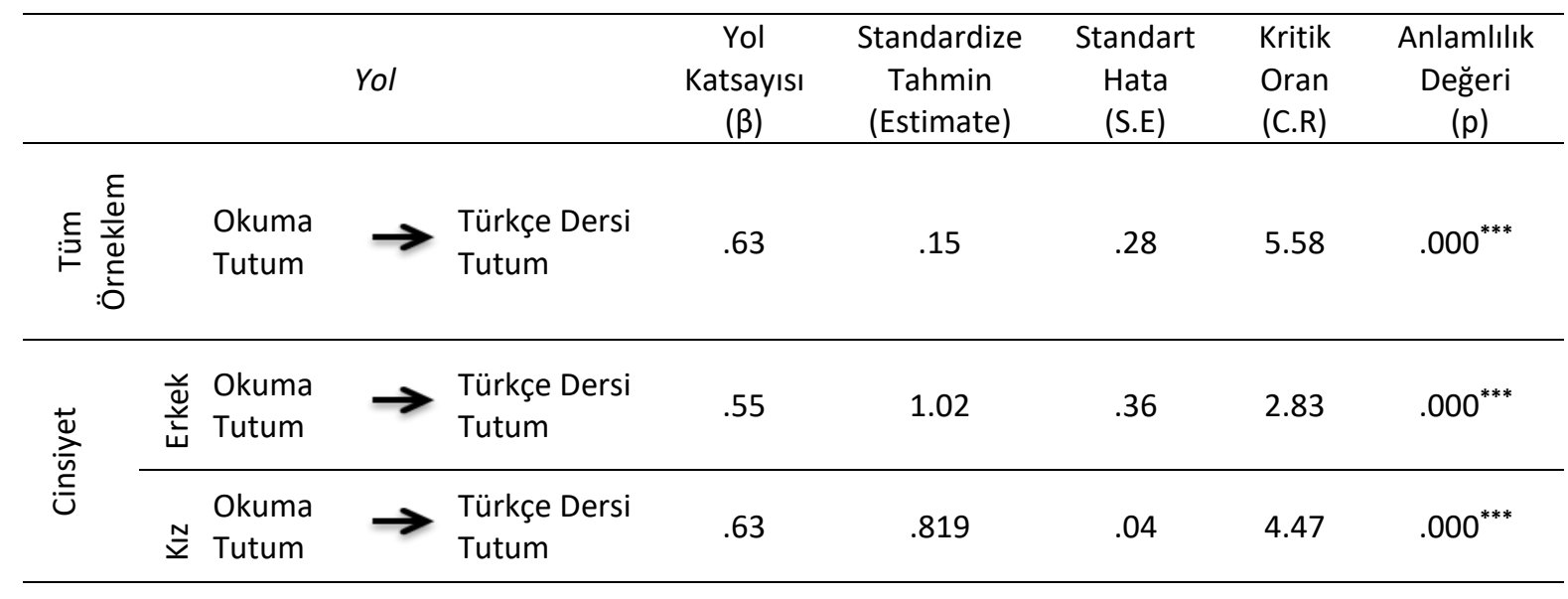

Tablo 3'e göre tüm hipotezlerin veri tarafından desteklendiği görülmüş ve hipotezlerin hepsi kabul edilmiştir. Tüm örnekleme ilişkin modelde Türkçe dersine yönelik tutumunun, okuma tutum tarafından pozitif yönde ve manidar düzeyde yordandığı görülmüş $(6=.63, p<.01)$ ve $H_{1}$ hipotezi kabul edilmiştir. Erkek öğrencilere ilişkin kurulan modelde Türkçe dersine yönelik tutumunun, okuma tutum tarafından pozitif yönde ve anlamlı düzeyde yordandığı görülmüş $(B=.55, p<.01)$ ve $\mathrm{H}_{2}$ hipotezi kabul edilmiştir. Kız öğrencilere ilişkin kurulan modelde Türkçe dersine yönelik tutumunun, okuma tutum tarafından pozitif yönde ve anlamlı düzeyde yordandığı görülmüş $(6=.63, p<.01)$ ve $\mathrm{H}_{3}$ hipotezi kabul edilmiştir. 
Tablo 4. Standartlaştırılmış doğrudan, dolaylı ve toplam etki büyüklükleri

\begin{tabular}{|c|c|c|c|c|c|c|c|}
\hline & & \multirow{2}{*}{ Tahmin edilen } & \multirow{2}{*}{$\mathrm{R}^{2}$} & \multirow{2}{*}{ Tahmin eden } & \multicolumn{3}{|c|}{ Standartlaştırılmış Tahminler } \\
\hline & & & & & Doğrudan & Dolaylı & Toplam \\
\hline $\begin{array}{l}\text { Tüm } \\
\text { Örneklem }\end{array}$ & & $\begin{array}{c}\text { Türkçe Dersi } \\
\text { Tutum }\end{array}$ & .40 & $\begin{array}{l}\text { Okuma } \\
\text { Tutum }\end{array}$ & .63 & --- & .63 \\
\hline \multirow[t]{2}{*}{ Cinsiyet } & 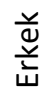 & $\begin{array}{c}\text { Türkçe Dersi } \\
\text { Tutum }\end{array}$ & .30 & $\begin{array}{l}\text { Okuma } \\
\text { Tutum }\end{array}$ & .55 & --- & .55 \\
\hline & $\underline{\underline{N}}$ & $\begin{array}{c}\text { Türkçe Dersi } \\
\text { Tutum }\end{array}$ & .40 & $\begin{array}{l}\text { Okuma } \\
\text { Tutum }\end{array}$ & .63 & --- & 63 \\
\hline
\end{tabular}

Tablo 4'e göre tüm örnekleme ilişkin modelde okuma tutumun, Türkçe dersine ilişkin tutum üzerinde doğrudan ve toplamda yüksek bir etki $(d=.63)$ oluşturduğu ve Türkçe dersine ilişkin varyansın \%40'lık kısmını açıkladığı görülmüştür. Erkek öğrencilere ilişkin modelde okuma tutumun, Türkçe dersine ilişkin tutum üzerinde doğrudan ve toplamda yüksek bir etki ( $d=.55$ ) oluşturduğu ve Türkçe dersine ilişkin varyansın \%30'luk kısmını açıkladığı görülmüştür. Kız öğrencilere ilişkin modelde okuma tutumun, Türkçe dersine ilişkin tutum üzerinde doğrudan ve toplamda yüksek bir etki $(d=.63)$ oluşturduğu ve Türkçe dersine ilişkin varyansın\%40'lık kısmını açıkladığı görülmüştür.

\section{Tartışma, Sonuç ve Öneriler}

$\mathrm{Bu}$ araştırmada okuma tutumunun, Türkçe dersine ilişkin tutum üzerindeki etkisine ve bu etkide cinsiyetin rolünün belirlenmesi için alan yazın taraması sonucunda oluşturulan hipotezlerin incelenmesi amaçlanmıştır. Hipotez modellerin test edilmesi sonucunda tüm modeller doğrulanmış ve oluşturulan hipotezlerin tümü kabul edilmiştir. Tüm örnekleme ilişkin oluşturulan modelde okuma tutumun, Türkçe dersine yönelik tutum üzerinde doğrudan, anlamlı ve yüksek bir etkiye ( $d=.63)$ sahip olduğu görülmüştür. Ayrıca bu modelde okuma tutum, Türkçe dersine yönelik tutuma ilişkin varyansın \%40'ık kısmını açıklamıştır. Bu bulgulardan hareketle okuma tutum ile Türkçe dersine ilişkin tutum arasındaki ilişkide okuma tutumun doğrudan ve yüksek düzeyde pozitif etki oluşturduğu tespit edilmiştir. Başka bir söylemle okuma tutum arttıkça, Türkçe dersine ilişkin tutumun da arttığı ve bu artışın yüksek düzeyde bir etki oluşturduğu söylenebilir. Benzer şekilde Mercan (2017)'ın 8. sınıf örnekleminde yaptığı araştırmada, okuma alışkanlığına ilişkin olumlu tutuma sahip öğrencilerin Türkçe dersine karşı daha olumlu bir tutum geliştirdiği ve derse karşı ilgi ve motivasyonlarının yüksek olduğu tespit edilmiştir. Baş ve Şahin (2012)'in araştırmasında ise öğrencilerin okuma tutumları, Türkçe dersi akademik başarılarının yaklaşık \%45'ini açıklamaktadır. Zorbaz ve Habeş (2015)'in araştırmasında ise ortaokul öğrencilerinin ders dışında okudukları kitap sayısı derse karşı tutumlarını etkilediği, okuma alışkanlığına ilişkin olumlu öz değerlendirme yapabilen öğrencilerin ise Türkçe dersine yönelik tutumlarının daha olumlu olduğu sonucuna ulaşılımıştır. Yaman ve Dağtaş (2013)'ın araştırmasında ise ekrandan okumanın da Türkçe dersine yönelik tutumu ve derse ilgiyi arttırdığı 


\section{6., 7. ve 8. Sınıf Öğrencilerinin Okuma Tutumlarının Türkçe Dersine ilişkin Tutum Üzerindeki Etkisinde Cinsiyetin Rolü: Bir Yapısal Eşitlik Modellemesi}

sonucuna ulaşılmıştır. Bu sonuçlar okuma eyleminin artışının Türkçe dersine yönelik tutumu etkilediğini desteklemekte ve okuma tutumun arttırılmasının gerekliliğini ortaya koymaktadır.

Okuma tutum ile Türkçe dersi arasındaki ilişkinin niteliğinin varlığına başka bir açıdan bakıldığında Türkçe Dersi Öğretim Programında, okumanın ve beraberinde öğrenmenin anlam kurmaya eş değer olarak ifade edildiği görülmektedir (MEB, 2015). Yani Türkçe dersinde öğrencinin öğrenme süreciyle ifade edilen okunulan nesneler arasındaki mana ilişkisini keşfederek anlam denilen ürünün açığa çıkışının sağlanmasıdır (Demirel, 1995). Öğrenme sürecinin okumayla direk ilişkisi ve öğrenmenin sürekli yenilenen bir olgu olmasından hareketle okuma davranışının sıklığı ve tekrarı öğrenme sürecini de hızlandırmaktadır. Okuma davranışının tekrarlanma olasılığının artışı da okumaya yönelik olumlu tutumla doğrudan ilişkilidir (Şahin-Taşkın ve Esen-Aygün, 2017; Umucu Alpoğuz, 2014). Buradan hareketle okuma becerisinin kazanılmasının ve geliştirilmesinin okumaya ilişkin sürdürülebilir olumlu tutumla doğrudan ilişkili olduğu görülmektedir (Akkaya ve Özdemir, 2013; Balcı, 2013; Balcı ve diğerleri, 2012; Gömleksiz, 2005; İşeri, 2010). Çünkü okuma tutum öğrencilerin okuma alışkanlığı kazanmaları ve bu alışkanlığın sürdürülebilir olmasında ve bilgi düzeylerinin yanı sıra akademik başarılarının artışında önemli bir etkendir (Conlon ve diğerleri, 2006; Martinez ve diğerleri, 2008; Roberts ve Wilson, 2006; Wilson ve Casey, 2007). Ayrıca okuma tutum ile okuma alışkanlığı (Suna, 2006; Bağcı, 2010), okuduğunu anlama beceri ve düzeyleri (Aydoğan, 2008; Kayıran, 2008; Sallabaş, 2008; Şeflek Kovacıoğlu, 2006) ile Türkçe dersi akademik başarı arasındaki (Güngör, 2009; Bağcı, 2010; Baş ve Şahin, 2012; Çam, 2006; Sallabaş, 2008) pozitif ilişki de bu sonuçları desteklemektedir. Çünkü okuma becerilerine sahip olmayan, okuduğunu anlayamayan öğrenciler akademik yaşamlarında da başarılı olamamaktadırlar (Özdemir, 1967). Ateş (2008) tarafından gerçekleştirilen araştırmada öğrencilerin Türkçe dersine yönelik tutumları, okuduğunu anlama düzeyleri, Türkçe dersi akademik başarısı ve genel akademik başarı arasında pozitif bir ilişki olduğu ortaya konulmuştur. Türkçe dersine ilişkin olumlu tutum, öğrenmenin artması ve beraberinde akademik başarının artmasını da sağlamaktadır (Bölükbaş, 2010; Çalışkan, 2004). Ayrıca Türkçe dersindeki akademik başarı (Kocaarslan, 2016; Baş ve Şahin, 2012; Karabay ve Kuşdemir Kayıran, 2010) ile genel akademik başarı arasındaki pozitif ilişki (Crosby, 2013; Ward, 2013; Kaniuka, 2010; Martinez ve diğerleri, 2008) bu dersin önemini ve bu dersin öncelikli hedeflerinden biri olan okuma becerisinin önemini ortaya koymaktadır. Öğrencilerin, okuduğunu anlama ile bilgi düzeyleri arasında pozitif ilişkinin (Egelioglu, 1993) yanı sıra Türkçe dersindeki akademik başarı ile genel akademik başarı arasındaki pozitif ilişkinin (Güvendir, 2014; Ateş, 2008) varlığı okuma becerisi ve akademik başarı arasındaki eş güdümlülüğü göstermektedir. Bununla birlikte Türkçe dersine ilişkin tutum ile Türkçe dersine ilişkin motivasyon arasındaki pozitif ilişki (Erdem ve Gözüküçük, 2013) diğer derslere tutumu da etkilemekte (Nas, 2003; Ünal ve Köse, 2014) ve öğrencinin derse karşı tutumu da öğrenme sürecini 
ve akademik başarısını etkilemektedir (Çalışkan, 2004; Çavuş ve Yaşar, 2010; Çörek, 2006; Erdem ve Gözüküçük, 2013; Fidan ve Eren, 2017; Fidan ve Baykul, 1994; Genç ve Kaya, 2010; Karasakaloğlu ve Saracaloğlu, 2009; Köse ve Ünal, 2014; She ve Fisher, 2002; Yenilmez ve Duman, 2008). Bu sonuçlar okumanın ve beraberinde okumayı etkileyen değişkenlerin derslere ilişkin tutumu ve öğrenme sürecinin her aşamasını doğrudan etkilediğini göstermektedir. Bu durumda okumaya ilişkin tutumun arttırımasının gerekliliğini ortaya koymaktadır.

Cinsiyet kapsamında oluşturulan modeller incelendiğinde ise kız öğrencilere ilişkin oluşturulan modelde okuma tutum, Türkçe dersine ilişkin tutumun \%40'ını, erkek öğrencilere ilişkin oluşturulan modelde ise \%30'unu açıkladığı görülmüştür. Bu bulgular okuma tutum ve Türkçe dersine yönelik tutum arasındaki ilişkinin cinsiyet açısından farklılık gösterdiğini ortaya koymaktadır. Cinsiyet açısından bu iki değişken arasındaki ilişkinin etkisine bakıldığında her iki modelde de dolaylı bir etki olmayıp, toplam ve doğrudan etkilerin birbirine eşit olduğu görülmüştür. Ayrıca kız öğrencilere ilişkin modeldeki doğrudan etki ( $d=.63)$, erkek öğrencilere ilişkin doğrudan etkiden ( $d=.55$ ) daha yüksek olmakla birlikte her iki modelde de okuma tutumun, Türkçe dersine ilişkin tutum üzerinde pozitif ve yüksek bir etkiye sahip olduğu görülmüştür. Bu bulgulardan hareketle okuma tutumunun, Türkçe dersine ilişkin tutum üzerindeki etkisi ve açıklama oranında cinsiyetin belirleyici bir etkiye sahip olduğu söylenebilir. Alan yazındaki araştırmalarda okuma tutumun, Türkçe dersine ilişkin tutum üzerindeki etkisini ve açıklama oranını cinsiyet açısından modelleyen bir araştırmaya erilememiştir. Ancak konuya okuma tutum açısından bakıldığında Sallabaş (2008)'ın 8. sınıf örnekleminde gerçekleştirdiği araştırmada kız öğrencilerin okuma tutumlarının, erkeklere göre manidar düzeyde farklılık gösterdiği tespit edilmiştir. Kız öğrencilerin okuma tutumlarının erkek öğrencilere göre daha yüksek oluşu birçok araştırma sonucuyla da örtüşmektedir (Akkaya ve Özdemir, 2013; Balcı ve diğerleri, 2012; Baş, 2012; Balcı, 2009; Bozpolat, 2010; Byro, 2000; Çeçen ve Deniz, 2015; Epçaçan, 2012; Logan ve Johnston, 2009; Öztürk ve diğerleri, 2016; Schatz ve Krashen, 2006; Schooten ve Glopper, 2002; Stokmans, 1999; Suna, 2006; Yalınkılıç, 2007). Türkçe dersine ilişkin tutum açısından değerlendirildiğinde ise tutumun, cinsiyet açısından örneklem farklılığına göre değişen bir kavram olduğu söylenebilir (Kazazoğlu, 2013). Zorbaz ve Habeş (2015)'in ortaokul; Kaya ve diğerlerinin (2009) 6, 7 ve 8. sınıf örnekleminde gerçekleştirdikleri araştırmada kız öğrencilerin Türkçe dersine ilişki tutumlarının, erkek öğrencilere göre daha yüksek olduğu görülmüştür. Benzer şekilde pek çok araştırmada kız öğrencilerin Türkçe dersine yönelik tutumlarının, erkeklere göre daha yüksek olduğu belirlenmiştir (Bıyıklı, 2014; Deniz ve Tuna, 2006; Kaya ve diğerleri, 2009; Bölükbaş, 2010; Gür ve diğerleri, 2013; Okur ve Özsoy, 2013). Bu sonuçlardan hareketle cinsiyetin gerek okuma tutum, gerekse Türkçe dersine ilişkin tutum üzerinde belirleyici bir etki oluşturduğu bununla birlikte okuma tutumun, Türkçe dersine yönelik tutumu açıklamada da kız öğrencilerin daha fazla açıklama ve etkiye 


\section{6., 7. ve 8. Sınıf Öğrencilerinin Okuma Tutumlarının Türkçe Dersine ilişkin Tutum Üzerindeki Etkisinde Cinsiyetin Rolü: Bir Yapısal Eşitlik Modellemesi}

sahip olduğu söylenebilir. Bu araştırmada ise cinsiyete ilişkin oluşturulan modellerden hareketle kız ve erkek öğrencilerin okuma tutumları arttıkça, Türkçe dersine ilişkin tutumlarının arttığı ve bu artışın kız öğrencilerde daha etkili olduğu söylenebilir. Gerek okuma becerisi gerekse Türkçe dersine ilişkin tutumu dilsel yetenek olarak bütün olarak değerlendirildiğinde kız öğrencilerin dil yeteneğinin daha erken geliştiği ve kızların erkeklere nazaran daha dil becerilerini kazanmaya daha yetkin ve eğilimli oldukları savunulmaktadır (Baroody ve Diamond, 2013; Güneş, 1997; Sackes, Işıtan, Avcı ve Justice, 2015). Ayrıca cinsiyete ilişkin modellere dair açıklama oranından hareketle de bu etkinin açığa çıkısında başka değişkenlerin de etkili olduğu söylenebilir. Nitekim Ünlü (2014), öğrencilerin Türkçe dersine yönelik tutumları ile öz yeterlik düzeyleri arasında pozitif yönde bir korelasyon olduğunu; öğrencilerin akademik, sosyal ve duygusal öz yeterlik düzeyleri yükseldikçe Türkçe dersine yönelik tutumlarının geliştiği ortaya koymuştur. Okuma, okuduğunu anlama becerileri ve okumaya yönelik tutumun gelişiminin, Türkçe dersine ilişkin tutumun gelişimine olumlu yönde etkisinin yanı sıra bilişsel ve duyuşsal becerilerin gelişimine de katkı sağladığı bilinmektedir (Demirel ve Epçaçan, 2012; Gelen, 2003; Mercan, 2017). Bu iki değişkenin başka değişkenlerle ilişkisinden hareketle gerek tüm örnekleme ilişkin modele gerekse cinsiyete dayalı olarak oluşturulan modellere eklenecek başka değişkenlerle bu etkinin açığa çıkışındaki başka faktörlerin varlığı tespit edilerek okuma tutumun ve beraberinde Türkçe dersine yönelik tutumun arttırılmasına katkı sağlanabilir. Bu sonuçlardan hareketle şu önerilerde bulunulabilir.

\section{Öneriler}

1. Kız ve erkek öğrencilere ilişkin oluşturulan modellerdeki açıklama oranı ve etki düzeyinden hareketle bu farklılığın sebepleri nitel araştırmalarla derinlemesine incelenebilir.

2. Okuma tutumun Türkçe dersine yönelik tutum üzerindeki yüksek etkisinden hareketle, okuma tutumu arttıracak farklı uygulamaların kullanıldığı deneysel çalışmalarla araştırma sonuçları sınanabilir.

3. Bu araştırma 6,7 ve 8 . sınıf düzeyiyle sınırlı olup modelin geçerliliği ve bulguların genellenebilirliği çeşitli öğretim kademelerini (ilköğretim, orta öğretim, üniversite ortaokul) kapsayacak araştırmalarla sınanabilir.

4. Okuma tutumunun, Türkçe dersine ilişkin tutumun üzerindeki etkisine dair oluşturulan modellere ilişkin tüm sonuçlar, Türkçe dersine ilişkin tutumu etkileyen başka değişkenler olduğunu göstermektedir. Bu sonuçlardan hareketle modele eklenecek başka değişkenlerle modelin geçerliliği yeniden sınanabilir. 
5. Okuma tutumun pozitif yöndeki yüksek etkisinin ve bu etkide cinsiyeti rolünden hareketle öğretmenlerin okuma tutumu arttırmak için cinsiyete dayalı farklııkların ön plana çıkarıldığı uygulamalara ağırlık verilmelidir.

6. Erkek öğrencilerin okumaya ve beraberinde Türkçe dersine ilişkin tutumu arttıracak bireysel çalışmalar yapılabilir.

\section{Kaynaklar}

Akkaya, N., \& Özdemir, S. (2013). Ortaöğretim öğrencilerinin okumaya yönelik tutumlarının incelenmesi- İzmirBuca örneği. Bartın Üniversitesi Eğitim Fakültesi Dergisi, 2(1), 75-96.

Akkılık, R. (2011). Türkiye okuma kültürü haritası. Türk Kütüphaneciliği, 25(2), 326-329.

Aktaş, A. (2013). Türkşe öğretimi dersi başarı düzeyi ile tutum ve üstbilişssel becerilerin etkileşimi. Yayımlanmamış yüksek lisans tezi. Trakya Üniversitesi, Sosyal Bilimler Enstitüsü, Edirne.

Akyol, H., (2005). Türkşe Ilk okuma yazma öğretimi. Ankara: PegemA Yayıncılık.

Alexander, J. E., \& Filler, R. C. (1976). Attitudes and reading. Newark, DE: International Reading Association.

Altınok, H. (2004). Cinsiyet ve başarı durumlarına göre ilköğretim 5.sınıf öğrencilerinin fen bilgisi dersine yönelik tutumları. Eğitim Araştırmaları Dergisi, 17, 81-91.

Ateş, M. (2008). Ilköğretim ikinci kademe öğrencilerinin okuduğunu anlama düzeyleri ile Türkçe dersine karşı tutumları ve akademik başarıları arasındaki ilişki. Yayımlanmamış doktora tezi. Selçuk Üniversitesi, Sosyal Bilimler Enstitüsü, Konya.

Aydın, i. S., Kaya, N. S., \& Bayraktar, U. (2015). Türkçe öğretiminde öğrenci tutumlarına yönelik yazılan makaleler üzerine meta-analiz çalışması. International Journal of Languages' Education and Teaching, 3(6), 95-118.

Aydoğan, R. (2009). Okumaya karşı olumlu ve olumsuz tutuma sahip 6. sınıf öğrencilerinin Türkçe dersinde kullandıkları okuduğunu anlama stratejileri ve yaratııılık düzeyleri. Yayımlanmamış yüksek lisans tezi. Dokuz Eylül Üniversitesi, Eğitim Bilimleri Enstitüsü, İzmir.

Bağcı, H. (2010). Illköğretim II. kademe öğrencilerinin okumaya yönelik tutumlarının değerlendirilmesi. II. Uluslararası Dünya Dili Türkçe Sempozyumu (9-11 Aralık 2009) Bildirileri, Lefkoşa: Uluslararası Kıbrıs Üniversitesi.

Balıı, A. (2009). Illköğretim 8. sınıf öğrencilerinin okuma alışkanlık ve ilgileri üzerine bir araştırma. Yayımlanmamış doktora tezi. Gazi Üniversitesi, Eğitim Bilimleri Enstitüsü, Ankara.

Balıı, A., Uyar, Y., \& Büyükikiz, K. K. (2012). İlköğretim 6. sınıf öğrencilerinin okuma alışkanlıkları, kütüphane kullanma sıklıkları ve okumaya yönelik tutumlarının incelenmesi. Turkish Studies, 7(4), 965-985.

Balcı, A. (2013). Okuma ve anlama eğitimi. Ankara: Pegem Akademi Yayıncılık.

Baroody, A. E., \& Diamond, K. E. (2013). Measures of preschool children's interest and engagement in literacy activities: Examining gender differences and construct dimensions. Early Childhood Research Quartely, 28(2), 291-301.

Baş, G. (2012). Reading attitudes of high school students: an analysis from different variables. International Journal on New Trends in Education and Their Implications, 3(2), 47-58.

Baş, G., \& Şahin, C. (2012). Illköğretim 6. 7. ve 8. sınıf öğrencilerinin okuma tutumları ve yazma eğilimleri ile Türkçe dersindeki akademik başarıları arasındaki ilişki. Turkish Studies, 7(3), 555-572.

Belet, Ş. D. (2005). Öğrenme stratejilerinin okuduğunu anlama ve yazma becerileri ile Türkçe dersine ilişkin tutumlara etkisi. Yayımlanmamış doktora tezi. Anadolu Üniversitesi, Eğitim Bilimleri Enstitüsü, Eskişehir.

Bıyıklı, C. (2014). Ortaokul öğrencilerinin Türkçe dersine yönelik tutumları ve akademik benlik kavramları. Uludağ Üniversitesi Eğitim Fakültesi Dergisi, 27(1), 231-254. 


\section{6., 7. ve 8. Sınıf Öğrencilerinin Okuma Tutumlarının Türkçe Dersine ilişkin Tutum Üzerindeki Etkisinde Cinsiyetin Rolü: Bir Yapısal Eşitlik Modellemesi}

Bozpolat, E. (2010). Öğretmen adaylarının okuma alışkanlığına ilişkin tutumlarının değerlendirilmesi (Cumhuriyet üniversitesi eğitim fakültesi örneği). Zeitschrift für die Welt der Türken/Journal of World of Turks, 2(1), 411-428.

Bölükbaş, F. (2004). Ilköğretim öğrencilerinin Türkçe dersine yönelik tutumlarının başarı-cinsiyet-ailenin eğitim düzeyi bağlamında değerlendirilmesi. Yayımlanmamış doktora tezi. Dokuz Eylül Üniversitesi, Eğitim Bilimleri Enstitüsü, İzmir.

Bölükbaş, F. (2010). İlköğretim öğrencilerinin Türkçe dersine yönelik tutumlarının başarı-cinsiyet-ailenin eğitim düzeyi bağlamında değerlendirilmesi. Turkish Studies, 5(3), 905-918.

Byro, C. C. (2000). A study of the relationship between reading attitude and gender in the fourth grade children Unpublished doctoral disertation. Rowan University.

Campbell, M. B., \& Kmiecik, M. M. (2004). The greatest literacy challenges fa cing contemporary high school teachers: Implications for secondary teacher preparation. Reading Horizons, 45, 1-25.

Conlon, E. G., Zimmer-Gembeck, M. J., Creed, P. A., \& Tucker, M. (2006). Family history, self-perceptions, attitudes and cognitive abilities associated with early adolescent reading skills. Journal of Research in Reading, 29(1), 11-32.

Crosby, R. (2013). Reading attitudes as a predictor of latino adolescents' reading comprehension. Unpublished doctoral disertation. University Of California Riverside, California.

Çakır (Kozcu), N., Şenler, B., \& Taşkın (Göçmen), B. (2007). İlköğretim II. kademe öğrencilerinin fen bilgisi dersine yönelik tutumlarının belirlenmesi. Türk Eğitim Bilimleri Dergisi, 5(4), 637-655.

Çalışkan, M. (2004). Ilköğretim 8. sınıf öğrencilerinin tutum ve akademik benlik tasarımının başarıya etkisi. Selçuk Üniversitesi, Sosyal Bilimler Enstitüsü, Konya.

Çam, B. (2006). Illköğretim öğrencilerinin görsel okuma düzeyleri ile okuduğunu anlama, eleştirel okuma ve Türkçe dersi akademik başarıları arasındaki ilişki. Yayımlanmamış yüksek lisans tezi. Osmangazi Üniversitesi, Sosyal Bilimler Enstitüsü, Eskişehir.

Çavuş, Ş., \& Yaşar, F. Ö. (2010). Sınıf öğretmeni adaylarının "Türk dili I ses ve yapı bilgisi” dersine yönelik tutumlarının değerlendirilmesi. Ahi Evran Üniversitesi Eğitim Fakültesi Dergisi, 11(2), 187-208.

Çeçen, M. A., \& Deniz, E. (2015). Lise öğrencilerinin okumaya yönelik tutumları (Diyarbakır ili örneği). Mustafa Kemal Üniversitesi Sosyal Bilimler Enstitüsü Dergisi, 12(30), 193-212.

Çınar, İ. (2002). Kuram ve uygulamalarıyla ilk okuma yazma öğretimi. Malatya: Öz Serhat Yayınları.

Demir, C., \& Yapıcı, M. (2007). Ana dili olarak Türkçenin öğretimi ve sorunları. Sosyal Bilimler Dergisi, 9(2), 177192.

Demirel, M. (1993). Öğrenme stratejilerinin öğretilmesi. Eğitim ve Bilim, 17(83), 52-59.

Demirel, Ö. (2002). Türkçe ve sınıf öğretmenleri için Türkçe öğretimi. Ankara: PegemA Yayıncılık.

Demirel, Ö., \& Epçaçan, C. (2012). Okuduğunu anlama stratejilerinin bilişsel ve duyuşsal öğrenme ürünlerine etkisi. Kalem Eğitim ve Insan Bilimleri Dergisi, 2(1), 71-106.

Deniz, S., \& Tuna, S. (2006). illköğretim öğrencilerinin Türkçe dersine yönelik tutumları: Köyceğiz örneklemi. Millî Eğitim Dergisi, 170, 339-350.

Dağtaş, A. (2013). Ekrandan okumanın okumaya ve Türkçe dersine yönelik tutuma etkisi. Yayımlanmamış yüksek lisans tezi. Sakarya Üniversitesi, Eğitim Bilimleri Enstitüsü, Sakarya.

Egelioğlu, V. (1993). Okuduğunu anlama düzeyinin ve öğrenme için harcanan zamanın bilişsel öğrenme düzeyine etkisi. Eğitim Bilimleri Birinci Ulusal Kongresi Bildirileri I, 24-28 Eylül 1990, Ankara.

Epçaçan, C. (2012). Ortaokul öğrencilerinin eleştirel okuma becerileri ile okumaya ilişkin tutumları arasındaki ilişki. Turkish Studies, 7(4), 1711-1726.

Erdem, A. R., \& Gözüküçük, M. (2013). İlköğretim 3. 4. ve 5. sınıf öğrencilerinin Türkçe dersine yönelik motivasyonu ve tutumları arasındaki ilişki. Pegem Ĕ̆itim ve Öğretim Dergisi, 3(2), 13-24. 
Fidan, M., \& Eren, A. (2017). Ortaokul öğrencilerinin Türkçe dersine yönelik tutum görünümleri ile eğitime ilişkin motivasyonları arasındaki ilişkiler. Hacettepe Üniversitesi Eğitim Fakültesi Dergisi (H. U. Journal of Education), 32(2), 480-493.

Fidan, N., \& Baykul, Y. (1994). İlköğretimde temel öğrenme ihtiyaçlarının karşılanması. Hacettepe Üniversitesi Eğitim Fakültesi Dergisi, 10(10), 7-20.

Gelen, ì. (2003). Bilişsel farkındalık stratejilerinin Türkçe dersine ilişkin tutum, okuduğunu anlama ve kalıcılığa etkisi. Yayımlanmamış doktora tezi, Çukurova Üniversitesi, Sosyal Bilimler Enstitüsü, Adana.

Genç, G., \& Kaya, A. (2010). Sınıf öğretmeni adaylarının yabancı dil dersine yönelik tutumları ile yabancı dil akademik başarıları arasındaki ilişki. 9. Ulusal Sınıf Öğretmenliği Eğitimi Sempozyumu. Elazığ. s. 10191022.

Gömleksiz, M. N. (2005). Geleceğin öğretmenlerinin kitap okumaya ilişkin görüşlerinin değerlendirilmesi. Yüzüncü Yıl Üniversitesi, Elektronik Eğitim Fakültesi Dergisi, 1(1), 1-21.

Güneş, F. (2009). Hızlı okuma ve anlamı yapılandırma. Ankara: Nobel Yayın Dağıtım.

Güneş, F. (2007). Türkçe öğretimi ve zihinsel yapılandırma. Ankara: Nobel Yayıncılık.

Gür, T., Dilci, T., Şener, H., \& Yıldırım, T. (2013). 4. sınıf öğrencilerinin Türkçe dersine yönelik tutumlarına bazı değişkenlerin etkileri. Cumhuriyet International Journal of Education, 2(1), 118-134.

Hu, L., \& Bentler, M. (1999). Cutoff criteria for fit indexes in covariance structure analysis: Conventional criteria versus new alternatives. Structural Equation Modeling: A Multidisciplinary Journal, 6(1), 1-55.

Isşeri, K. (2010). The investigation of the reading attitudes of second grade students. Journal of Human Sciences, 7(2), 468-487.

Jöreskog, K. G., \& Sörbom, D. (1993). Lisrel 8: Structural equation modeling with the simplis command languange. Scientific Software İnternational, Inc. USA.

Kaniuka, T. S. (2010). Reading achievement, attitude toward reading, and reading self-esteem of historically low achieving students. Journal of Instructional Psychology, 37(10), 184-188.

Karabay, A., \& Kuşdemir Kayıran, B. (2010). İlköğretim beşinci sınıf öğrencilerinin okuduğunu anlama becerileri ve okumaya ilişkin tutumları arasındaki ilişki. Çukurova Üniversitesi Eğitim Fakültesi Dergisi, 3(38), 110-117.

Karahan, B., \& Taşdan, M. (2016). 5. ve 6. sınıf öğrencilerinin okumaya karşı tutum ve motivasyonlarının okuduğunu anlama becerileri ile ilişkisi. Uluslararası Türkçe Edebiyat Kültür Eğitim Dergisi, 5(2), 949969.

Karasakaloğlu, N., \& Saracaloğlu, A. S. (2009). Sınıf öğretmeni adaylarının Türkçe derslerine yönelik tutumları, akademik benlik tasarımları ile başarıları arasındaki ilişki. Yüzüncü Yıl Üniversitesi Eğitim Fakültesi Dergisi, 6(1), 343-362.

Karasar, N. (2011). Bilimsel araştırma yöntemi. Ankara: Nobel Yayın Dağıtım.

Karatay, H. (2011). Okuma eğitimi kuram ve uygulama. Ankara: Berikan Yayınevi.

Katrancı, M. (2015). İlkokul dördüncü sınıf öğrencilerinin yazma ve kitap okuma motivasyonlarının incelenmesi. Ana Dili Ĕgitimi Dergisi, 3(2), 49-62.

Kaya, A. i., Arslantaş, H. i., \& Şimşek, N. (2009). İlköğretim öğrencilerinin Türkçe dersine karşı tutumlarının değerlendirilmesi. Elektronik Sosyal Bilimler Dergisi, 8(30), 376-387.

Kayıran, B. K. (2007). Çoklu zekâ kuramı destekli Kubaşık öğrenme yönteminin Türkçe dersine ilişkin tutuma ve okuduğunu anlama başarısına etkisi. Yayımlanmamış yüksek lisans tezi. Çukurova Üniversitesi Sosyal Bilimler Enstitüsü, Adana.

Kazazoğlu, S. (2013). Türkçe ve İngilizce derslerine yönelik tutumun akademik başarıya etkisi. Eğitim ve Bilim, 38(170), 294-307.

Keleş, Ö. (2006). İlköğretim 4. ve 5. sınıf öğrencilerinde kitap okuma alışkanlığının incelenmesi. Yayımlanmamış yüksek lisans tezi. Gazi Üniversitesi Eğitim Bilimleri Enstitüsü, Ankara. 


\section{6., 7. ve 8. Sınıf Öğrencilerinin Okuma Tutumlarının Türkçe Dersine ilişkin Tutum Üzerindeki Etkisinde Cinsiyetin Rolü: Bir Yapısal Eşitlik Modellemesi}

Klem, L. (2000). Structural equation modeling. L. Grimm ve P. Yarnold (Ed.), Reading and understanding multivariate statistics (Vol. II). Washington, DC: American Psychological Association.

Kline, R. B. (2011). Principles and practice of structural equation modeling. New York and London: The Guilford Press.

Kocaarslan, M. (2016). An exploratory study of the relationships between reading comprehension competence, reading attitude and the vividness of mental imagery among Turkish fourth-grade students. International Electronic Journal of Elementary Education, 8(4), 675-686.

Köse, M., \& Ünal, F. T. (2014). Türkçe dersine yönelik tutum ölçeği geliştirilmesi: bir geçerlilik ve güvenirlik çalışması. Bartın Üniversitesi Eğitim Fakültesi Dergisi. (3)2, 233-249.

Logan, S., \& Johnston, R. (2009). Gender differences in reading ability and attitudes: Examining where these differences lie. Journal of Research in Reading, 32(2), 199-214.

Martinez, R. S., Aricak, O. T., \& Jewell, J. (2008). Influence of reading attitude on reading achievement: A test of the temporal-interaction model. Psychology in the Schools, 45(10), 1010-1023.

MEB. (2015). Illköğretim Türkçe dersi öğretim programı ve kılavuzu (1-8. sınıflar). Ankara: MEB Yayınları.

Mercan, M. (2017). Ortaokul 8. sınıf öğrencilerinin okumaya yönelik tutumları ile Türkçe dersine yönelik tutumları arasındaki ilişkinin incelenmesi. Yayımlanmamış yüksek lisans tezi. Atatürk Üniversitesi, Eğitim Bilimleri Enstitüsü, Erzurum.

Meydan, C. H., \& Şeşen, H. (2011). Yapısal eşitlik modellemesi AMOS uygulamaları. Ankara: Detay Yayıncılık.

McKenna, M. C., Kear, D. J. ve Ellsworth, R. A. (1995). Children's attitudes toward reading: A national survey. Reading Research Quarterly, 30(4), 934-956.

McKenna, M. C., Conradi, K., Lawrence, C., Jang, B. G. ve Meyer, J. P. (2012). Reading attitudes of middle school students: Results of a US survey. Reading Research Quarterly, 47(3), 283-306.

Morgan, P. L., \& Fuchs, D. (2007). Is there a bidirectional relationship between children's reading skills and reading motivation? Exceptional Children, 73(2), 165-183.

Nas, R. (2003). Türkçe öğretimi. Bursa: Ezgi Kitabevi.

Okur, A., \& Özsoy, Y. (2013). Üstün zekalı öğrencilerin Türkçe dersine yönelik tutumlarının incelenmesi: Bartın örneği. Eğitimde Kuram ve Uygulama. 9(3), 254-264.

Oktay, Y., \& Aktan, E. (1997). Çocuğun dil geliş̧iminde fonolojik duyarlılığı (ses bilgisel duyarlılığın) karşılaştırmalı olarak incelenmesi. 4. Ulusal Eğitim Kongresi Bilimleri Bildirileri, Eskisehir: Anadolu Üniversitesi.

Özbay, M., \& Uyar, Y. (2009). İlköğretim ikinci kademe öğrencileri için okumaya yönelik tutum ölçeğinin geliştirilmesi: Geçerlilik ve güvenirlik çalışması. Journal of New World Sciences Academy Education Sciences, 4(2), 632-651.

Özçelik, D. A. (1992). Eğitim programları ve öğretim. ÖSYM Yayınları, Ankara.

Özdemir, E. (1967). illkokul öğretmenleri için Türkçe öğretimi kılavuzu. Ansiklopedi Yayınevi.

Raykov, T., \& Marcoulides, G. A. (2008). An introduction to applied multivariate analysis. Taylor \& Francis Group, LLC.

Roberts, M. S., \& Wilson, J. D. (2006). Reading attitudes and instructional methodology: how might achievement become affected? Reading Improvement, 43(2), 64-69.

Saçkes, M., Işıtan, S., Avcı, K., \& Justice, L. M. (2016). Parents' perceptions of children's literacy motivation and their home-literacy practices: What's the connection?. European Early Childhood Education Research Journal, 24(6), 857-872.

Sallabaş, M. E. (2008). İlköğretim 8. sınıf öğrencilerinin okumaya yönelik tutumları ve okuduğunu anlama becerileri arasındaki ilişki. Inönü Üniversitesi Eğitim Fakültesi Dergisi, 9(16), 141-155.

Saracaloğlu, A. S. (2000). Öğretmen adaylarının yabancı dile yönelik tutumları ile akademik başarıları arasındaki ilişki. Eğitim ve Bilim, 25(115), 65-72. 
Schatz, A., \& Krashen, S. (2006). Attitudes toward reading in grades 1-6. Knowledge Quest, 35(1), 46-48.

She, H. C., \& Fisher, D. (2002). Teacher communication behavior and its association with students' cognitive and attitudinal outcomes in science in Taiwan. Journal of Research in Science Teaching, 39(1), 63-78.

Suna, Ç. (2006). Ilköğretim öğrencilerinin okuma ilgi ve alışkanlıklarını etkileyen etmenlerin analitik olarak incelenmesi ve değerlendirilmesi. Yayımlanmamış yüksek lisans tezi, Anadolu Üniversitesi Eğitim Bilimleri Enstitüsü, Eskişehir.

Stokmans, M. J. W. (1999). Reading attitude and its effect on leisure time reading. Poetics, 26, 245-261.

Şahinli, A. (2008). Hikâye okumanın okuduğunu anlamaya ve Türkçe dersine yönelik tutuma etkisi. Yayımlanmamış yüksek lisans tezi. Dokuz Eylül Üniversitesi, Eğitim Bilimleri Enstitüsü, İzmir.

Şahin-Taşkın, Ç., \& Esen-Aygün, H. (2017). İlkokul öğrencilerinin okuma tutumlarının çeşitli değişkenler açısından incelenmesi. Ilköğretim Online, 16(3), 1120-1136.

Şeflek Kovacıoğlu, N. (2006). Ilköğretim ikinci sınıflarında aile çevresi ve çocuğun okumaya karşı tutumu ile okuduğunu anlama becerisi arasındaki ilişkiler. Yayımlanmamış yüksek lisans tezi. Yıldız Teknik Üniversitesi, Sosyal Bilimler Enstitüsü, İstanbul.

Umucu Alpoğuz, D. (2014). Algılanan ana-baba tutumlarının ilköğretim öğrencilerinin okumaya yönelik tutumlarına ve Türkçe dersi akademik başarılarına etkisi. Yayımlanmamış yüksek lisans tezi. Ahi Evran Üniversitesi, Sosyal Bilimler Enstitüsü, Kırşehir.

Ünal, E. (2006). ilköğretim öğrencilerinin eleştirel okuma becerileri ile okuduğunu anlama ve okumaya ilişkin tutumları arasındaki ilişki. Yayımlanmamış yüksek lisans tezi. Osmangazi Üniversitesi Sosyal Bilimler Enstitüsü, Eskişehir.

Ünlü, S. (2014). Ortaokul öğrencilerinin Türkçe dersine yönelik tutumları ve öz yeterlikleri arasındaki ilişki. Yayımlanmamış yüksek lisans tezi. Çanakkale Onsekiz Mart Üniversitesi, Eğitim Bilimleri Enstitüsü, Çanakkale.

Ward, S. L. (2013). An examination of a relationship between reading attitudes and reading achievement for a group of sixth grade students. Unpublished doctoral disertation. Mississippi State, Mississippi.

Wilson, J. D., \& Casey, L. H. (2007). Understanding the recreational reading patterns of secondary students. Reading Improvement, 44(1), 40-49.

Yalınkılıç, K. (2007). Türkçe öğretmen adaylarının okumaya ilişkin tutum ve görüşleri. Uluslararası Sosyal Araştırmalar Dergisi, 1(1), 225-241.

Yaman, H., \& Dağtaş, A. (2013). Ekrandan okumanın Türkçe dersine yönelik tutuma etkisi. The Journal of Academic Social Science Studies, 6(7), 1233-1250.

Yamashita, J. (2007). The relationship of reading attitudes between L1 and L2: An investigation of adult EFL learners in Japan. TESOL Quarterly, 41(1), 81-105.

Yenilmez, K., \& Duman, A. (2008). İlköğretimde matematik başarısını etkileyen faktörlere ilişkin öğrenci görüşleri. Manas Üniversitesi Sosyal Bilimler Dergisi, 19, 251-268.

Zorbaz, K. Z., \& Habeş, M. (2015). Ortaokul öğrencilerinin Türkçe dersine yönelik tutumlarının çeşitli değişkenler açısından incelenmesi. Kastamonu Eğitim Dergisi, 23(4), 1737-1756.

\section{Extended Abstract \\ Introduction}

Reading is not only the interpretation and vocalization of symbols, but also it is a vital process that is established between the reader and the text for the protection and the transfer of cultural values (Keleş, 2006). Reading is, however, a nurturing power that provides the development of an individual's feelings as well as her/his universe of thought (Katrancl, 2015). The importance of this skill is further enhanced by the fact that the learning-teaching process takes place substantially through reading, understanding and speaking by the materials based on the language (Güneş, 2009; Oktay and Aktan, 1997). One of the ultimate goals aimed at acquiring reading skills is to turn this skill into a habit (Demirel, 2002; Güneş, 2007; Karatay, 2011). One of the factors in the acquisition of reading habits is the reading attitude (Aydın, Kaya and Bayraktar, 2015). The development of reading attitude (Conlon, Zimmer-Gembeck, Creed and Tucker, 2006; Yamashita, 2007) which affects all components of the reading process has a positive effect on the development of the attitude towards 


\section{6., 7. ve 8. Sınıf Öğrencilerinin Okuma Tutumlarının Türkçe Dersine ilişkin Tutum Üzerindeki Etkisinde Cinsiyetin Rolü: Bir Yapısal Eşitlik Modellemesi}

Turkish course (Demirel and Epçaçan, 2012; Gelen, 2003; Mercan, 2017). Positive attitude towards Turkish course also affects academic achievement positively (Aktaş, 2013, Ateş, 2008). The studies in the literature indicate that the achievements aimed for Turkish course have not been attained adequately (Demir and YapıcI, 2007; Kaya et al., 2009), the students have not found themselves academically adequate in Turkish course (Bıyıklı, 2014) and their reading skills have not improved sufficiently yet (Akkılık, 2011; Baş, 2012; Campbell and Kmiecik, 2004; Çeçen and Deniz, 2015; İşeri, 2010; McKenna, Conradi, Lawrence, Jang and Meyer, 2012; Schatz and Krashen, 2006). As a result of the analysis, various studies investigating the relation between the reading skill and the attitude towards Turkish course were reached (Mercan, 2017, Dağtaş, 2013, Ateş, 2008, Şahinli, 2008), but any studies related to the effect of reading attitude on the attitude towards Turkish course and its explanation ratio on the attitude towards Turkish course were not reached. It is aimed to eliminate this deficiency in the field and to examine the role of the reading attitude, which is an important argument of the learning process, on the attitude towards Turkish course and the role of gender on this effect through structural equality modeling.

\section{Method}

This research aims to determine the effect of reading attitudes of the 6th, 7th and 8th grade students on the attitude towards Turkish course and the role of gender on this effect as well as the explanation ratio of the reading attitudes._The study was designed_in the relational screening model. In the relevant model, it is aimed to determine the interchange of two or more variables or gradation of this change (Karasar, 2011). Participants in the study consists of 317 students attending to 6th, 7th and 8th grades of three middle schools selected by simple random sampling from random sampling methods. When examining demographic characteristics; 170 (55.5\%) of the students were female, and 147 (46.4\%) were male and 148 (46.7\%), of participants were on the 6th grade, $103(32.5 \%)$ of them were on the 7th grade and $66(20.8 \%)$ were on the 8th grade. The data of the research were collected using Reading Attitude Scale and Attitude Scale towards Turkish course. In the analysis of the data, Structural Equation Modeling (SEM) was used to analyze the relationship between the variables.

\section{Result and Discussion}

In this study, the hypothesis about the effect of reading attitude on the attitude of Turkish course and the role of gender on this effect was examined by structural equation modeling. As a result of testing the hypothesis models generated as a result of the literature search, all models were verified and all hypotheses generated were accepted. In the model for the whole sample, the reading attitude has a direct,significant and high effect on the attitude towards Turkish course and explains about $40 \%$ of the variance related to the Turkish course. From these findings, it was determined that the reading attitude had a high level of explanation rate and directly a high level of positive effect on the attitude towards Turkish course. In other words, as the reading attitude increases, the attitude towards Turkish course also increases. Similarly, Mercan (2017) found in his research on 8th grade students that students with positive attitudes towards reading habits developed a more positive attitude towards Turkish course. In the study of Baş and Şahin (2012), the reading attitudes of the students explained about $45 \%$ of the academic achievements of Turkish course. In the study of Zorbaz and Habeş (2015), it was determined that the number of books read by middle school students affected their attitudes towards Turkish course positively. When looking at the relationship between reading attitude and Turkish course, the basic stage of the learning process in Turkish course is to discover the meaning connection between the reading texts (Demirel, 1995). The positive attitude towards reading increases the likelihood of recurrence of reading behaviors (Şahin-Taşkın and Esen-Aygün, 2017; Umucu Alpoğuz, 2014), acquisition and development of reading skills are directly related to the positive attitude towards reading (Akkaya and Özdemir, 2013; Balcı et al., 2012; Gömleksiz, 2005; İşeri, 2010). Ateş (2008) points out that there is a positive relationship between students' attitudes towards Turkish course, level of comprehension, Turkish course academic achievement and general academic achievement. Similar researches found that the relationship between Turkish course academic achievement (Kocaarslan, 2016; Baş and Şahin, 2012) and general academic achievement and the positive relationship between reading comprehension and knowledge level (Egelioglu, 1993) indicated the effect of Turkish course and reading skills on the learning process.

When the models generated within the scope of gender are examined; it can be seen that reading attitude in the model for female students explains $40 \%$ of the attitude towards Turkish course and $30 \%$ of it in the model related to male students. When the gender-related models were examined in terms of effects, it was seen that there was no indirect effect in both models and the total and direct effects were equal to each other. In addition, it can be said that the direct effect $(d=.63)$ in the model for female students is higher than the one for male students $(d=.55)$, but both models have a positive and high effect on the reading attitude and the attitude towards Turkish course. From these findings, it was determined that the reading attitude differed in its 
effect on the attitude towards Turkish course and its explanation rate according to gender. In the literature, there was no research modeling this relationship, but the attitudes of female students were higher than those of male students (Akkaya and Özdemir, 2013; Baş, 2012; Balcı, 2009; Bozpolat, 2010; Byro, 2000; Çeçen and Deniz, 2015; Epçaçan, 2012; Logan and Johnston, 2009; Schatz and Krashen, 2006; Yalınkılıç, 2007). When we look at the attitude towards Turkish course, it can be said that the attitude differs in terms of gender variable (Kazazoğlu, 2013). According to the various studies, such as Zorbaz and Habeş (2015)'s study on secondary school students, Kaya et al. (2009)'s study conducted with 6th, 7th and 8th graders and some other researches (Bıyıklı, 2014; Deniz and Tuna, 2006; Kaya et al., 2009; Bölükbaş, 2010, Gür et al.; 2013, Okur and Özsoy, 2013), the attitudes of female students towards Turkish course are higher than those of males.

Based on the explanation rates of all models, it can be said that there are other variables on the attitude towards Turkish course, apart from the reading attitude. However, positive and high relationship between these two variables indicates that increasing reading attitude has a very important effect in increasing attitude towards Turkish course. 